\title{
New gastropod records for the Eastern Mediterranean Sea and one new alien (Emarginula decorata Deshayes, 1863) for the Mediterranean Sea from NW Aegean Sea, Greece
}

\author{
Thanasis Manousis $^{1 \dagger}$ and Sofia Galinou-Mitsoudi ${ }^{2^{*+}}$
}

\begin{abstract}
Background: The NW Aegean Sea has a complex topography, high quality waters, oligotrophic to eutrophic conditions, is connected with estuaries and wetlands, is of high ecological interest, harbours all the types of human activities and yet few researchers work on its marine biodiversity. With this study, the contribution to the knowledge of the Hellenic and Eastern Mediterranean gastropod biodiversity of the studied families is continued, and an expansion of the search in other substrates and deeper waters of the NW Aegean Sea with emphasis on the minor in size species during the period from October 2008 to January 2014.

Results: Thirty seven species belonging to seven families (Cerithiopsidae, Fissurellidae, Phasianellidae, Scissurellidae, Siliquariidae, Skeneidae, and Triphoridae) were identified and their biodiversity was compared with the current checklists of marine gastropod molluscs for the Hellenic Seas based on previous surveys. In this collection of gastropods, one species (Emarginula decorata Deshayes, 1863) is a new alien for the Mediterranean Sea, 14 species are new for the Eastern Mediterranean Sea and 16 species are new for the Hellenic fauna (with the one above mentioned alien species included). The main identification characteristics and ecological information such as habitat, distribution, alien expansion paths to the NW Aegean Sea and origin of the species are given and discussed.
\end{abstract}

Conclusions: The Hellenic gastropod biodiversity of the studied families was enriched with 37 new records for the N Aegean Sea, out of which 16 are new for Greece, 14 are new for the Eastern Mediterranean Sea while one (Emarginula decorata) is a new alien for the Mediterranean Sea.

Keywords: Aegean Sea, Alien species, Biodiversity, Gastropods, Mediterranean Sea, Greece

\section{Background}

The N Aegean Sea comprises a marginal sea that connects the Eastern Mediterranean basin with the Black Sea through the Dardanelles Strait. Its North West (NW) area exhibits a complex topography that includes estuarine areas, long gulfs and peninsulas of both shallow and deep, and high quality waters (51 or $13 \%$ of the 393 blue flags of Greece, $2^{\text {nd }}$ world rank for 2013 by Blue Flag [1] of depths up to $1500 \mathrm{~m}$ in the western

\footnotetext{
*Correspondence: galimits@otenet.gr

${ }^{\dagger}$ Equal contributors

${ }^{2}$ Alexander Technological Educational Institute of Thessaloniki, Department of Fisheries \& Aquaculture Technology, 632 00, Nea Moudania, Chalkidiki, Greece Full list of author information is available at the end of the article
}

part of the N Aegean Trough [2] (Figure 1)). The area receives significant loads of riverine nutrients and lowsalinity productive waters from the Black Sea. In the surface of the open sea (around the peninsulas of Chalkidiki as well as in the Toronaeos Gulf), the concentration of chl-a is low $\left(0.2 \mu \mathrm{g} \mathrm{l}^{-1}\right)$ rising to eutrophic levels by the estuaries while its values are much higher $\left(0.4 \mu \mathrm{g} \mathrm{l}^{-1}\right)$ close to the bottom [3].

Thermaikos Gulf (with the second big for Greece City and Port of Thessaloniki) is affected by the riverine loads and the human activities (agriculture, mussel culture, fishery and industry at the N and W coasts; tourism and navigation at the E and SW of 1250000 people) [4]. 


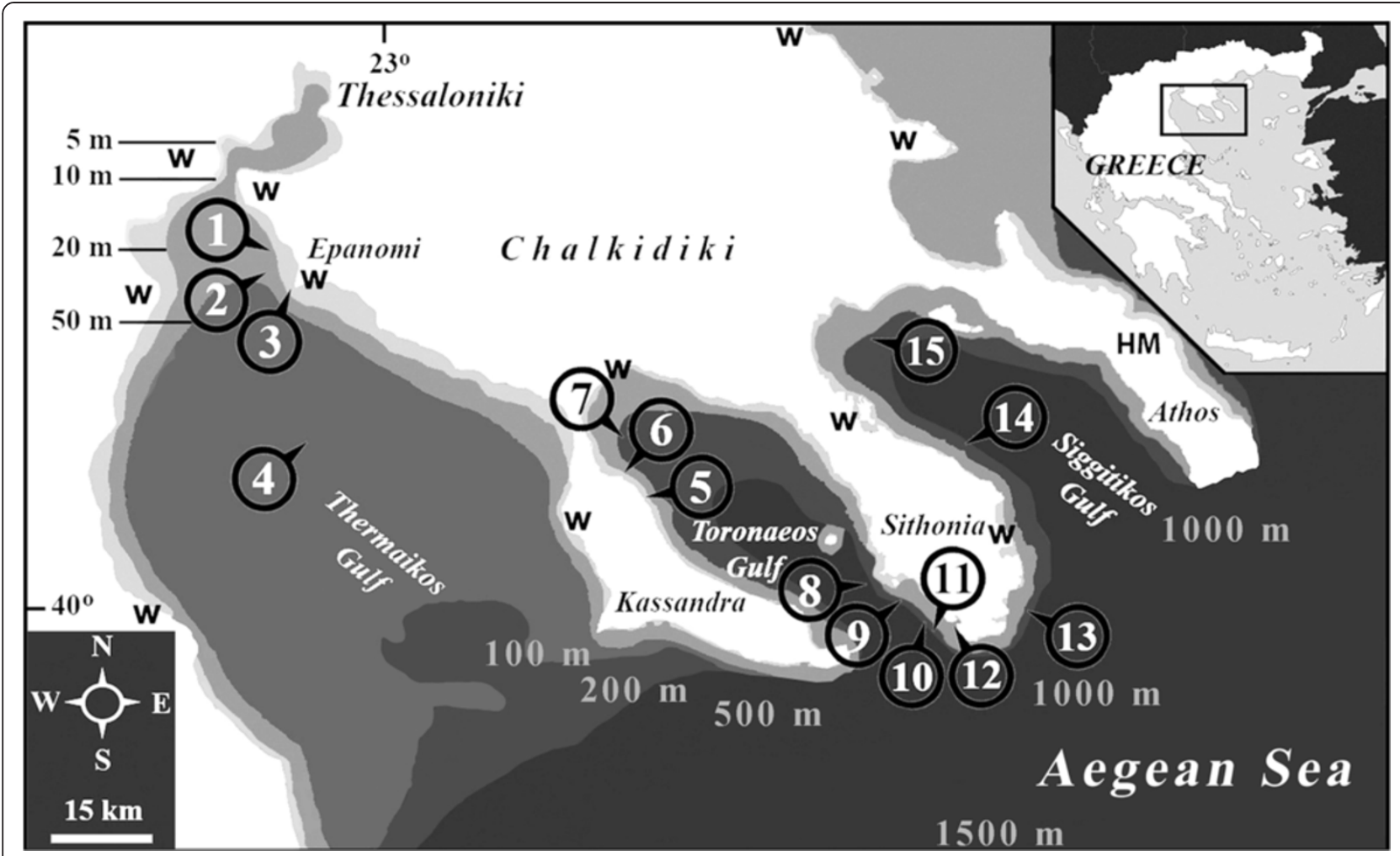

Figure 1 Map of studied area. Stations in Thermaikos Gulf: 1. Palioura; 2. Paralia of Epanomi; 3. Cape of Epanomi; 4. Central Thermaikos Gulf. Stations in Chalkidiki: 5. Afitos; 6. Nea Fokaia; 7. NW Toronaeos Gulf; 8. Spalathonisia; 9. Tristinika; 10. Marathia; 11. Toroni; 12. Porto Koufo; 13. Ampelos; 14. Central Siggitikos Gulf; 15. Pyrgadikia. The protected by NATURA 2000 wetland areas (w) as well as the Holy Mount of monaster life and unique flora in Athos peninsula (HM), are also indicated.

In between the three Peninsulas of Chalkidiki, the Toronaeos and Siggitikos Gulfs are deep marine basins of high quality waters with coasts of variable type from calm and sandy to exposed rocky cliffs; 70000 people live permanently in that area employed in jobs related to tourism and agriculture while in the summer that number increases sharply with the tourists to an estimated 1200000 [4].

As a whole, the ecological importance of the NW Aegean coastal zones is based upon the high quality of the sea water, the small or extended wetlands (all protected by NATURA 2000 and Ramsar Convention) and the Mount Athos Peninsula (Figure 1) with its virgin forests and the incredible floristic biodiversity all aided by the monastic life of its inhabitants. In addition, NW Aegean comprises one of the main oil tanker and cargo ship traffic routes of the E Mediterranean Sea [5] - known vectors for the transfer of alien organisms.

After a long and slow cooling period from the late 1960 s to the early 1990s, Aegean Sea started to warm rapidly. The warming rate over 1992-2008 was several times higher than the estimated global mean warming rate over the same period [6]. During the early 1990s, a significant change in the E Mediterranean thermohaline circulation was observed, that of the shift of dense waters from the Adriatic Sea to the Aegean Sea, a phenomenon now known as the "Eastern Mediterranean Transient" [3]. These environmental changes were not followed by extensive faunistic studies and thus their impact on the biodiversity of the area was not assessed. Only few and sporadic investigations are referred to the gastropod fauna of the Hellenic Seas - mainly as a part of faunistic research (e.g. [7-12]) - and fewer are referred to the NW Aegean Sea with most recent those of Manousis et al. [13] and among the previews publications by Sakellariou [7], Tenekidis [8], Koutsoubas et al. [9], Antoniadou et al. [10] and Koroneos [14]. At the same time, it is known that progress in benthos research, human activities and environmental conditions change significantly the recorded marine biodiversity while detailed and persisting surveys usually increase the number of the recorded species, mainly of those of small size [15-18].

The aim of this study was: a) to continue contributing to the knowledge of the Hellenic gastropod biodiversity with an updated list for the gastropod species of the 
studied families from the NW Aegean Sea, and b) to expand the research effort in other substrates and deeper waters.

\section{Results}

The records

As a result of this investigation, approximately 150 specimens were collected and 37 species were identified. They are listed within families in Table 1 and presented in Figures 2, 3, 4, 5, 6 and 7. Among the identified species, 14 are recognized as new for the gastropods fauna of E Mediterranean Sea and 16 are referred for the first time to the Hellenic fauna, one of which is alien. The alien is Emarginula decorata Deshayes, 1863 was referred from the SE Africa, Reunion Islands and Red Sea and is recorded for the first time from the Mediterranean Sea. All species with data on their habitat, mode of life and origin are presented in Table 1.

\section{Documented first records for the Hellenic waters}

The specimens' descriptions per family with basic ecogeographical information for the new records are given below:

\section{Fissurellidae}

Emarginula decorata Deshayes, 1863 (synonym of E. spinosa) (Figure 2a).

Collection station One live individual ( $16.55 \mathrm{~mm}$ long, $11.35 \mathrm{~mm}$ wide and $7.80 \mathrm{~mm}$ high) was found on a sponge collected from mixed bottom at $120 \mathrm{~m}$ depth of station 14 .

Description The strong and oval shell has a moderately high profile, a very small slightly coiled apex located at the posterior $1 / 5$ and a slightly curved base that makes it rest on its anterior and posterior margins. The sculpture consists of 55-57 alternating strong and weaker radial ribs more or less of equal strength by the posterior margin and interspaces equally wide as the ribs. High co-marginal cords form tubers when passing over the ribs and produce a prominent lattice. Wide and rectangular slit reaching $1 / 8$ the distance between the anterior margin and the apex. Color; yellowish white.

Similar species At first impression, E. decorata looks similar to some native Mediteranean species. Nevertheless, although it is of a similar oval shape as E. christiaensi Piani, 1985 it has a lower profile and a more prominent sculpture; it has a less coiled apex and more prominent sculpture than E. sicula JE Gray, 1825 with the ratio of the length of the fissure to the distance to the shell's apex to be $1 / 9$ in $E$. spinosa [21], while it is $<1 / 5$ in E. sicula according to Gofas et al. [22]; it is much lower and more oval than E. fissura (Linnaeus, 1758) and it is of more oval shape and higher than E. octaviana Coen, 1939.

Habitat and distribution It was found live foraging on a sponge. Its known distribution is from SE Africa [23], Reunion, Arabian Gulf and Red Sea [21].

Status Emarginula decorata Deshayes, 1863 is recently referred as a synonym of $E$. spinosa Deshayes, 1863 [21,24,25] while the World Register of Marine Species [23] accepts Emarginula spinosa Deshayes, 1863 as a separate species from E. decorata Deshayes GP, 1863.

\section{Scissurellidae}

Anatoma micalii Geiger, 2012 (Figure 2b).

Collection station Four shells $(0.75-0.85 \mathrm{~mm}$ long and $0.85-1.00 \mathrm{~mm}$ wide) were found in detritus material trapped in small scale fishing nets at $120 \mathrm{~m}$ depth from mixed bottom of station 14 .

Description The very delicate, biconic, pearly white and rather depressed in its outline shell is formed by a globose spiral of two finely reticulate convex whorls that are flattened above and rapidly enlarging. The protoconch is approximately $3 / 4$ of a whorl succeeded by the teleoconch I that bears $17-18$ axial ribs in $3 / 4$ of a whorl and exhibits an elevation of the spire by the upper outer lip immediately before the onset of the selenizone of the teleoconch. The teleoconch II sculpture consists of numerous fine, curved and longitudinal axial ribs, interrupted by a long furrow with raised margins (selenizone) and intersected by dense minute spiral striae in the interstices. Six of those spiral striae on the upper part (roof) of the shell over the selenizone stand out as they are more robust than the rest. The furrow lies at nearly one-third of the whorl's height from the suture and is deep, striated across and with sharp and prominent edges forming a peripheral carina. The aperture is oblique and the peristome continuous with a thin outer lip. The inner lip is folded back on the columella without covering the umbilicus. The umbilicus is deep, funnelshaped, exposing only the body whorl and bearing a very prominent funiculus which starts from behind the edge of the inner lip.

Similar species Based on descriptions and detailed figures of Geiger [26] and the Anatoma micalii specimens of this study, A. micalii is similar, though smaller by half to $A$. aspera (Philippi, 1844) (an inhabitant of the Greek Seas) but differs from the late in that a) it has proportionally more wide the two carinas of the selenizone, b) it has a more rapidly enlarging and, 
Table 1 Gastropods records, habitat and distribution details (in the study area)

\begin{tabular}{|c|c|c|c|c|c|c|c|c|c|c|}
\hline \multirow{2}{*}{$\begin{array}{l}\text { FAMILY (the change of } \\
\text { species number/genus, } \\
\% \text { additions for Greece } \\
\text { based on Koukouras [19] } \\
\text { and Manousis et al. [17]) }\end{array}$} & \multirow[t]{2}{*}{ Species } & \multirow{2}{*}{$\begin{array}{l}\text { New record } \\
\text { R: Greece } \\
\text { EM: E Medit. } \\
\text { A: Alien in Medit. }\end{array}$} & \multicolumn{3}{|c|}{ The collection Stations in the Gulfs } & \multirow{2}{*}{$\begin{array}{l}\text { Zone/Depth } \\
(\mathrm{m})\end{array}$} & \multirow[t]{2}{*}{ Habitat } & \multirow[t]{2}{*}{ Mode of life [20] } & \multirow[t]{2}{*}{ Found } & \multirow[t]{2}{*}{ Origin } \\
\hline & & & $\begin{array}{l}\text { Thermaikos } \\
\text { (1-4 stations) }\end{array}$ & $\begin{array}{c}\text { Toronaeos } \\
\text { (5-12 stations) }\end{array}$ & $\begin{array}{c}\text { Siggitikos: } \\
\text { (13-15 stations) }\end{array}$ & & & & & \\
\hline \multirow[t]{3}{*}{ FISSURELLIDAE } & $\begin{array}{l}\text { Emarginula adriatica } \\
\text { Costa, } 1829\end{array}$ & & 1 & 9,10 & 14,15 & $10-120$ & $\begin{array}{l}\text { Posidonia, \& } \\
\text { mixed bottom }\end{array}$ & Feeds on sponges & $\begin{array}{l}\text { Alive \& } \\
\text { shells }\end{array}$ & Mediterranean Sea \\
\hline & $\begin{array}{l}\text { Emarginula decorata } \\
\text { Deshayes, } 1863\end{array}$ & $R, E M, A$ & & & 14 & 120 & Mixed bottom & Feeds on sponges & Alive & Red Sea \& SE Africa \\
\hline & $\begin{array}{l}\text { Emarginula huzardii } \\
\text { (Payraudeau, 1826) }\end{array}$ & & 1,3 & $5,7,9,12$ & 14 & 60 & $\begin{array}{l}\text { Zostera, biogenic } \\
\text { \& mixed bottom }\end{array}$ & Feeds on sponges & $\begin{array}{l}\text { Alive \& } \\
\text { shells }\end{array}$ & Mediterranean Sea \\
\hline \multirow[t]{3}{*}{$\begin{array}{c}(6 \text { species from } 5 \\
20 \% \text { for the genus) }\end{array}$} & $\begin{array}{l}\text { Emarginula octaviana } \\
\text { Coen, } 1939\end{array}$ & & & & 15 & $10-45$ & $\begin{array}{l}\text { Biogenic \& mixed } \\
\text { bottom }\end{array}$ & Feeds on sponges & Alive & Mediterranean Sea \\
\hline & $\begin{array}{c}\text { Emarginula rosea } \\
\text { Bell, } 1824\end{array}$ & & 1 & $8,9,12$ & 14 & $10-60$ & $\begin{array}{l}\text { Biogenic \& mixed } \\
\text { bottom }\end{array}$ & Feeds on sponges & Shells & Mediterranean Sea \\
\hline & $\begin{array}{l}\text { Emarginula sicula } \\
\text { Gray, } 1825\end{array}$ & & 3 & & & 9 & Mixed bottom & Feeds on sponges & $\begin{array}{l}\text { Alive \& } \\
\text { shell }\end{array}$ & Mediterranean Sea \\
\hline $\begin{array}{l}\text { SCISSURELLIDAE } \\
\text { (new genus for } \\
\text { Greece) }\end{array}$ & $\begin{array}{l}\text { Anatoma micalii } \\
\text { Geiger, } 2012\end{array}$ & $\mathrm{R}, \mathrm{EM}$ & & & 14 & 120 & Mixed bottom & Euryphagous & Shells & $\begin{array}{c}\text { W Mediterranean } \\
\text { Sea \& Sea of Marmara }\end{array}$ \\
\hline No change & $\begin{array}{l}\text { Scissurella costata } \\
\text { d' Orbigny, } 1824\end{array}$ & & 1,2 & $7,8,11$ & 14 & $10-70$ & $\begin{array}{c}\text { Posidonia \& } \\
\text { biogenic bottom }\end{array}$ & $\begin{array}{l}\text { Feeds on live plant } \\
\text { matter }\end{array}$ & $\begin{array}{l}\text { Alive \& } \\
\text { shells }\end{array}$ & Mediterranean Sea \\
\hline $\begin{array}{l}\text { SKENEIDAE (new } \\
\text { genus for Greece) }\end{array}$ & $\begin{array}{l}\text { Skeneoides exilissima } \\
\text { (Philippi, 1844) }\end{array}$ & $\mathrm{R}, \mathrm{EM}$ & 1 & & & 18 & Mixed bottom & Feeds on hydroids & Shell & W Mediterranean Sea \\
\hline \multirow[t]{2}{*}{ PHASIANELLIDAE } & $\begin{array}{l}\text { Tricolia pullus } \\
\text { (Linnaeus, 1758) }\end{array}$ & & 1,3 & 5 & 15,14 & $0-120$ & $\begin{array}{l}\text { Zostera, biogenic } \\
\& \text { mixed bottom }\end{array}$ & $\begin{array}{l}\text { Feeds on marine } \\
\text { algae and grasses }\end{array}$ & $\begin{array}{l}\text { Alive \& } \\
\text { shells }\end{array}$ & Mediterranean Sea \\
\hline & $\begin{array}{l}\text { Tricolia deschampsi } \\
\text { Gofas, } 1993\end{array}$ & $\mathrm{R}, \mathrm{EM}$ & & & 14 & 120 & Mixed bottom & $\begin{array}{l}\text { Feeds on marine } \\
\text { algae and grasses }\end{array}$ & Shell & Mediterranean Sea \\
\hline \multirow[t]{2}{*}{$\begin{array}{l}\text { (4 species from 3, } \\
33 \% \text { for the genus) }\end{array}$} & $\begin{array}{c}\text { Tricolia speciosa } \\
\text { (Von Muehlfeldt, 1824) }\end{array}$ & & 3 & & 15 & $0-30$ & Mixed bottom & $\begin{array}{l}\text { Feeds on marine } \\
\text { algae and grasses }\end{array}$ & $\begin{array}{l}\text { Alive \& } \\
\text { shells }\end{array}$ & Mediterranean Sea \\
\hline & $\begin{array}{l}\text { Tricolia tenuis } \\
\text { (Michaud, 1829) }\end{array}$ & & 1 & 5 & 14,15 & $5-60$ & $\begin{array}{l}\text { Zostera, biogenic } \\
\& \text { mixed bottom }\end{array}$ & $\begin{array}{l}\text { Feeds on marine } \\
\text { algae and grasses }\end{array}$ & $\begin{array}{l}\text { Alive \& } \\
\text { shells }\end{array}$ & Mediterranean Sea \\
\hline $\begin{array}{l}\text { SILIQUARIIDAE } \\
\text { (new genus for } \\
\text { Greece) }\end{array}$ & $\begin{array}{l}\text { Petalopoma elisabettae } \\
\text { Schiaparelli, } 2002\end{array}$ & $\mathrm{R}, \mathrm{EM}$ & 1,4 & 10 & 15 & $10-70$ & $\begin{array}{l}\text { Biogenic \& mixed } \\
\text { bottom }\end{array}$ & Feeds on sponges & $\begin{array}{l}\text { Alive \& } \\
\text { shells }\end{array}$ & $\begin{array}{c}\text { Central Mediterranean } \\
\text { Sea }\end{array}$ \\
\hline No change & $\begin{array}{l}\text { Tenagodus obtusus } \\
\text { (Schumacher, 1817) }\end{array}$ & & 1 & & & 10 & Mixed bottom & Feeds on sponges & Shells & Mediterranean Sea \\
\hline $\begin{array}{l}\text { TRIPHORIDAE } \\
\text { No change }\end{array}$ & $\begin{array}{l}\text { Marshallora adversa } \\
\text { (Montagu, 1903) }\end{array}$ & & 3,4 & & & $60-70$ & Mixed bottom & Feeds on sponges & Shells & Mediterranean Sea \\
\hline \multirow{2}{*}{$\begin{array}{l}\text { (3 species from } 2, \\
50 \% \text { for the genus) }\end{array}$} & $\begin{array}{c}\text { Monophorus enthrosoma } \\
\text { (Bouchet \& Guillemot, } \\
\text { 1978) }\end{array}$ & & 1 & & 14 & $5-120$ & Mixed bottom & Feeds on sponges & $\begin{array}{l}\text { Alive \& } \\
\text { shells }\end{array}$ & Mediterranean Sea \\
\hline & $\begin{array}{l}\text { Monophorus perversus } \\
\text { (Linnaeus, 1758) }\end{array}$ & & 3 & & & 0 & Zostera & Feeds on sponges & Shell & Mediterranean Sea \\
\hline
\end{tabular}


Table 1 Gastropods records, habitat and distribution details (in the study area) (Continued)

\begin{tabular}{|c|c|c|c|c|c|c|c|c|c|c|}
\hline & $\begin{array}{c}\text { Monophorus thiriotae } \\
\text { Bouchet, } 1985\end{array}$ & $\mathrm{R}$ & 4 & & 15 & $30-70$ & Mixed bottom & Feeds on sponges & $\begin{array}{l}\text { Alive \& } \\
\text { shells }\end{array}$ & Mediterranean Sea \\
\hline (new genus for Greece) & $\begin{array}{l}\text { Obesula marinostri } \\
\text { Bouchet, } 1985\end{array}$ & $R, E M$ & 1 & & & 10 & Mixed bottom & Feeds on sponges & Alive & W Mediterranean Sea \\
\hline \multirow{2}{*}{$\begin{array}{l}\text { ( } 2 \text { species from } 1 \\
100 \% \text { for the genus) }\end{array}$} & $\begin{array}{c}\text { Similiphora similior } \\
\text { (Bouchet \& Guillemot, } \\
\text { 1978) }\end{array}$ & & $1,2,3,4$ & 6 & & $0-70$ & $\begin{array}{l}\text { Zostera, biogenic } \\
\text { \& mixed bottom }\end{array}$ & Feeds on sponges & $\begin{array}{l}\text { Alive \& } \\
\text { shells }\end{array}$ & Mediterranean Sea \\
\hline & $\begin{array}{l}\text { Similiphora triclotae (Bouchet, } \\
\text { 1996) }\end{array}$ & $R, E M$ & 2 & & 14 & $40-60$ & Mixed bottom & Feeds on sponges & $\begin{array}{l}\text { Alive \& } \\
\text { shells }\end{array}$ & W Mediterranean Sea \\
\hline (new genus for Greece) & $\begin{array}{l}\text { Strobiligera flammulata } \\
\text { Bouchet \& Waren, } 1993\end{array}$ & $R, E M$ & & & 14,15 & $30-120$ & Mixed bottom & Feeds on sponges & $\begin{array}{l}\text { Alive \& } \\
\text { shell }\end{array}$ & $\begin{array}{l}\text { SW Mediterranean } \\
\text { Sea }\end{array}$ \\
\hline \multirow[t]{5}{*}{ CERITHIOPSIDAE } & $\begin{array}{l}\text { Cerithiopsis atalaya } \\
\text { Watson, } 1885\end{array}$ & $R, E M$ & 1,4 & & 15 & $10-70$ & Mixed bottom & Feeds on sponges & Shells & W Mediterranean Sea \\
\hline & $\begin{array}{l}\text { Cerithiopsis barleei } \\
\text { Jeffreys, } 1867\end{array}$ & & 1 & & 15 & $5-30$ & Mixed bottom & Feeds on sponges & $\begin{array}{l}\text { Alive \& } \\
\text { shells }\end{array}$ & Mediterranean Sea \\
\hline & $\begin{array}{l}\text { Cerithiopsis diadema } \\
\text { Monterosato, } 1874\end{array}$ & $R, E M$ & & & 14 & 60 & Mixed bottom & Feeds on sponges & Shell & $\begin{array}{l}\text { W \& Central } \\
\text { Mediterranean Sea }\end{array}$ \\
\hline & $\begin{array}{l}\text { Cerithiopsis fayalensis } \\
\text { Watson, } 1886\end{array}$ & $R, E M$ & 1 & & 14 & $20-120$ & Mixed bottom & Feeds on sponges & $\begin{array}{l}\text { Alive \& } \\
\text { shells }\end{array}$ & W Mediterranean Sea \\
\hline & $\begin{array}{l}\text { Cerirhiopsis horrida } \\
\text { (Monterosato, 1874) }\end{array}$ & & 4 & & & 70 & Mixed bottom & Feeds on sponges & Shell & Mediterranean Sea \\
\hline \multirow{6}{*}{$\begin{array}{l}\text { (11 species from 3, } \\
267 \% \text { for the genus) }\end{array}$} & $\begin{array}{c}\text { Cerithiopsis micallii } \\
\text { (Cecalupo \& Villari, 1997) }\end{array}$ & R, EM & 4 & & & 70 & Mixed bottom & Feeds on sponges & $\begin{array}{l}\text { Alive \& } \\
\text { shell }\end{array}$ & $\begin{array}{c}\text { W \& Central } \\
\text { Mediterranean Sea }\end{array}$ \\
\hline & $\begin{array}{l}\text { Cerithiopsis minima } \\
\text { (Brusina, 1865) }\end{array}$ & & 3 & & 14,15 & $0-30$ & Mixed bottom & Feeds on sponges & $\begin{array}{l}\text { Alive \& } \\
\text { Shells }\end{array}$ & Mediterranean Sea \\
\hline & $\begin{array}{l}\text { Cerithiopsis nana } \\
\text { Jeffreys, } 1867\end{array}$ & $\mathrm{R}$ & 1 & & 15 & $5-50$ & Mixed bottom & Feeds on sponges & $\begin{array}{l}\text { Alive \& } \\
\text { shell }\end{array}$ & Mediterranean Sea \\
\hline & $\begin{array}{l}\text { Cerithiopsis cf. oculisfictis } \\
\text { Prkic \& Mariottini, } 2010\end{array}$ & R, EM & 4 & & & 100 & Mixed bottom & Feeds on sponges & Alive & Mediterranean Sea \\
\hline & $\begin{array}{l}\text { Cerithiopsis scalaris } \\
\text { (Locard, 1892) }\end{array}$ & & 1 & & & 10 & Mixed bottom & Feeds on sponges & Shell & Mediterranean Sea \\
\hline & $\begin{array}{l}\text { Cerithiopsis tubercularis } \\
\text { (Montagu, 1803) }\end{array}$ & & $1,2,4$ & & & $5-70$ & Mixed bottom & Feeds on sponges & $\begin{array}{l}\text { Alive \& } \\
\text { shells }\end{array}$ & Mediterranean Sea \\
\hline \multirow{2}{*}{$\begin{array}{l}\text { (2 species from } 1 \\
100 \% \text { for the genus) }\end{array}$} & $\begin{array}{l}\text { Dizoniopsis concatenata } \\
\text { (Conti, 1864) }\end{array}$ & R, EM & 1 & & & $20-30$ & Mixed bottom & Feeds on sponges & $\begin{array}{l}\text { Alive \& } \\
\text { shells }\end{array}$ & $\begin{array}{c}\text { Central Mediterranean } \\
\text { Sea }\end{array}$ \\
\hline & $\begin{array}{l}\text { Dizoniopsis coppolae } \\
\text { (Aradas, 1879) }\end{array}$ & & 1,4 & & & $20-70$ & Mixed bottom & Feeds on sponges & Shells & Mediterranean Sea \\
\hline No change & $\begin{array}{l}\text { Metaxia metaxa } \\
\text { (delle Chiaje, 1828) }\end{array}$ & & 1 & & $13,14,15$ & $10-70$ & $\begin{array}{l}\text { Biogenic \& mixed } \\
\text { bottom }\end{array}$ & Feeds on sponges & $\begin{array}{l}\text { Alive \& } \\
\text { shells }\end{array}$ & Mediterranean Sea \\
\hline
\end{tabular}




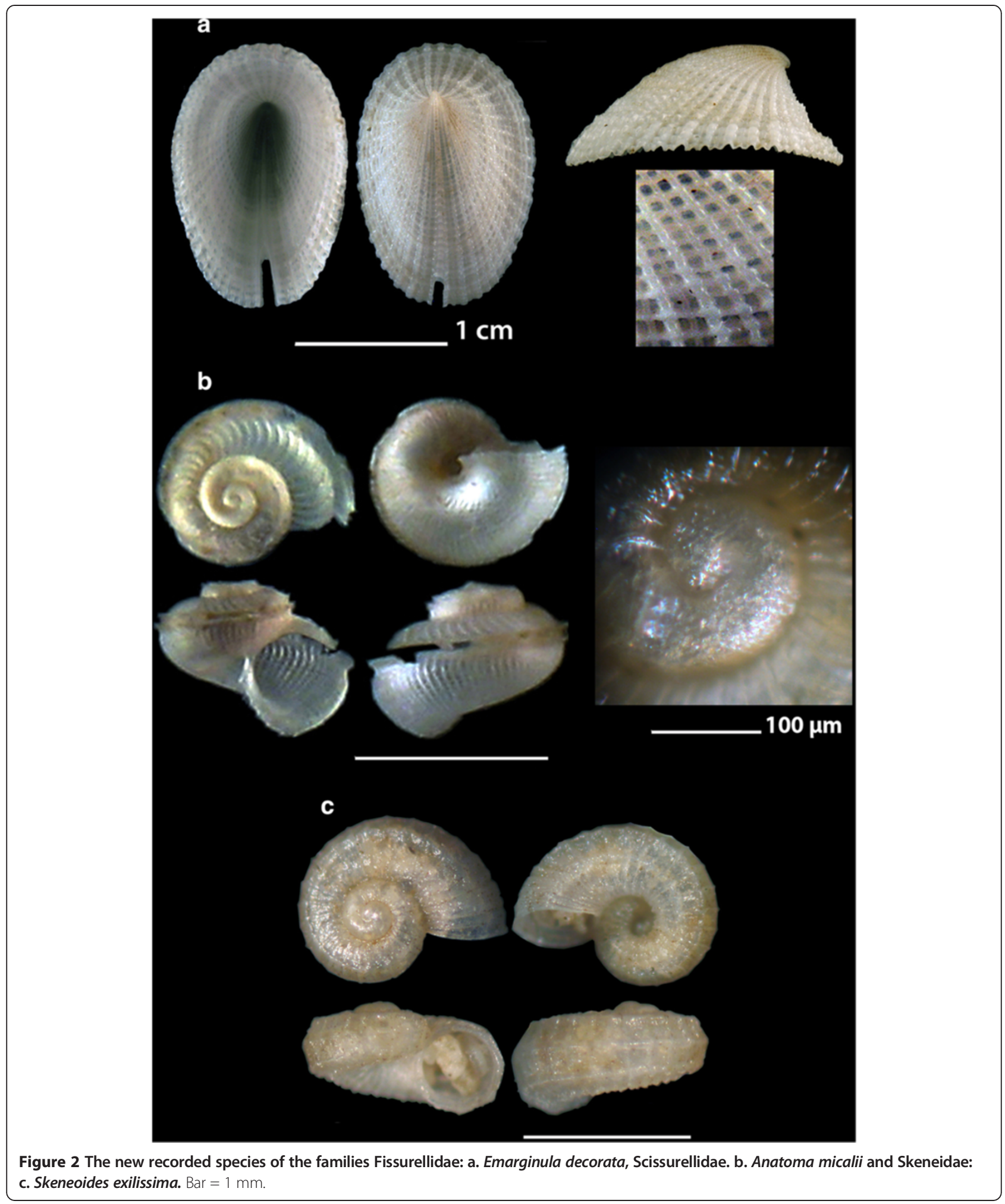

hence, more compressed spire, c) it has six prominent spiral striae on its upper part of the dome, d) its inner apertural lip does not cover the umbilicus, e) it has a more prominent funiculus by the umbilicus and $f$ ) it exhibits an elevation of the spire by the upper outer lip immediately before the onset of the selenizone. 


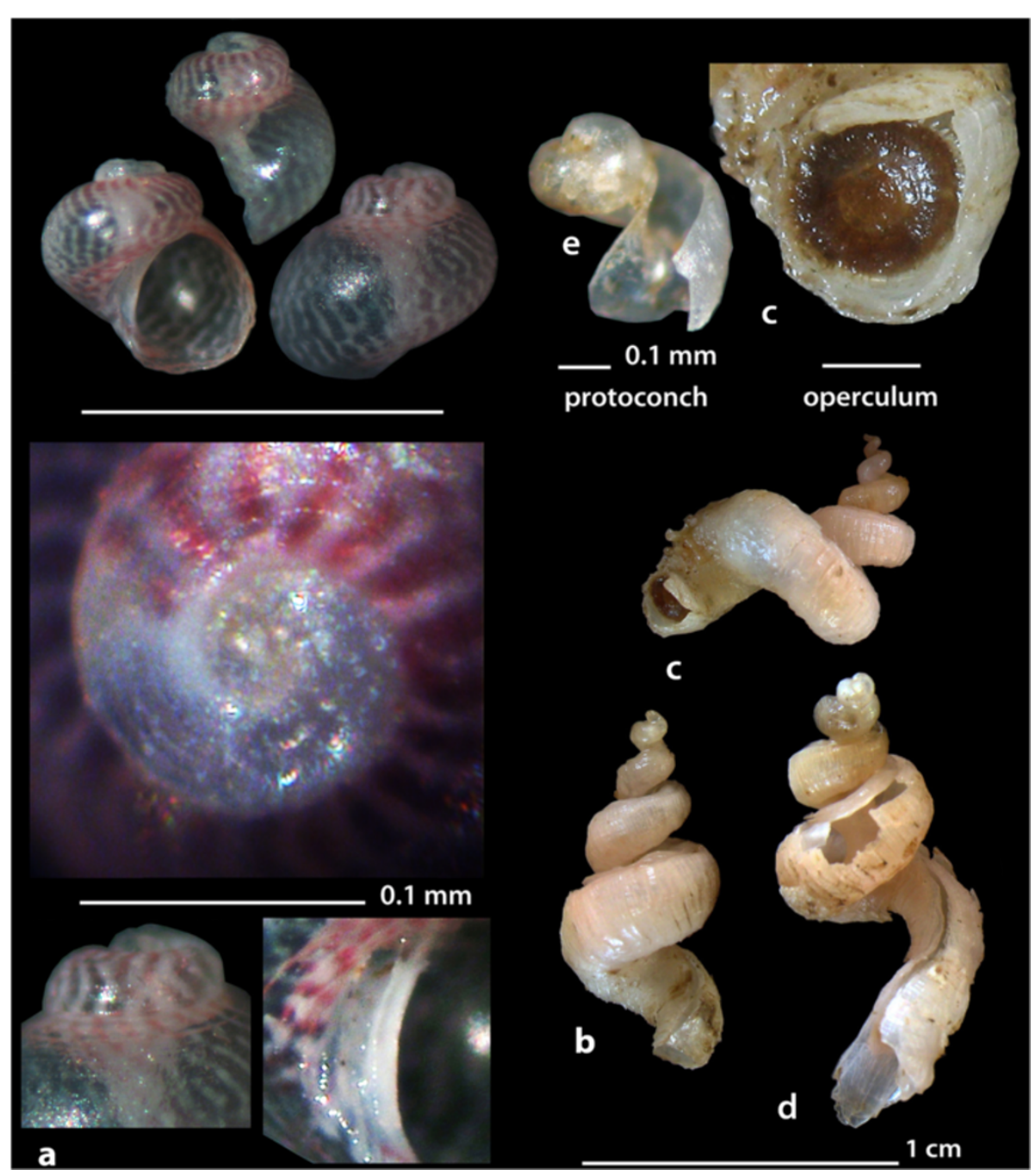

Figure 3 The new recorded species of the families Phasianellidae: a. Tricolia deschampsi and Siliquariidae: b, c, $d$ and e. Petalopoma elisabettae. Bar $=1 \mathrm{~mm}$ (unless otherwise indicated).

Habitat and distribution It lives on muddy-detrital bottoms of the circalittoral zone. The species has a rather wide distribution as it has been referred from Angola, Morocco (Strait of Gibraltar), the south coast of France, the west and south coasts of Italy and from the Bosporus [26].

Status It is a recently described new species by Geiger [26] who has re-identified erroneous references of Anatoma species from the Mediterranean Sea.

\section{Skeneidae}

Skeneoides exilissima (Philippi, 1844) (Figure 2c).

Collection station One shell $(0.60 \mathrm{~mm}$ long, $1.20 \mathrm{~mm}$ wide) was found in detritus material trapped in small scale fishing nets at $18 \mathrm{~m}$ depth from mixed bottom of station 1.

Description The pearly and uniformly white shell is almost planispiral and with a wide and deep umbilicus. Sculpture of 3 spiral cords per whorl visible on the spire, 4 evenly spaced spiral cords on the body whorl plus one on the umbilical wall; axial sculpture of fine, sharp, widely spaced and at equal interspaces axial ribs intersecting with the spiral cords and forming squarish pits. The aperture is circular, continuous and, due to the prominent spiral cords, with a honey comb cell-like periphery. The outer lip is simple.

Similar species Resembles Parviturbo fenestratus (Chaster, 1896) from which it differs in its much lower spire and 


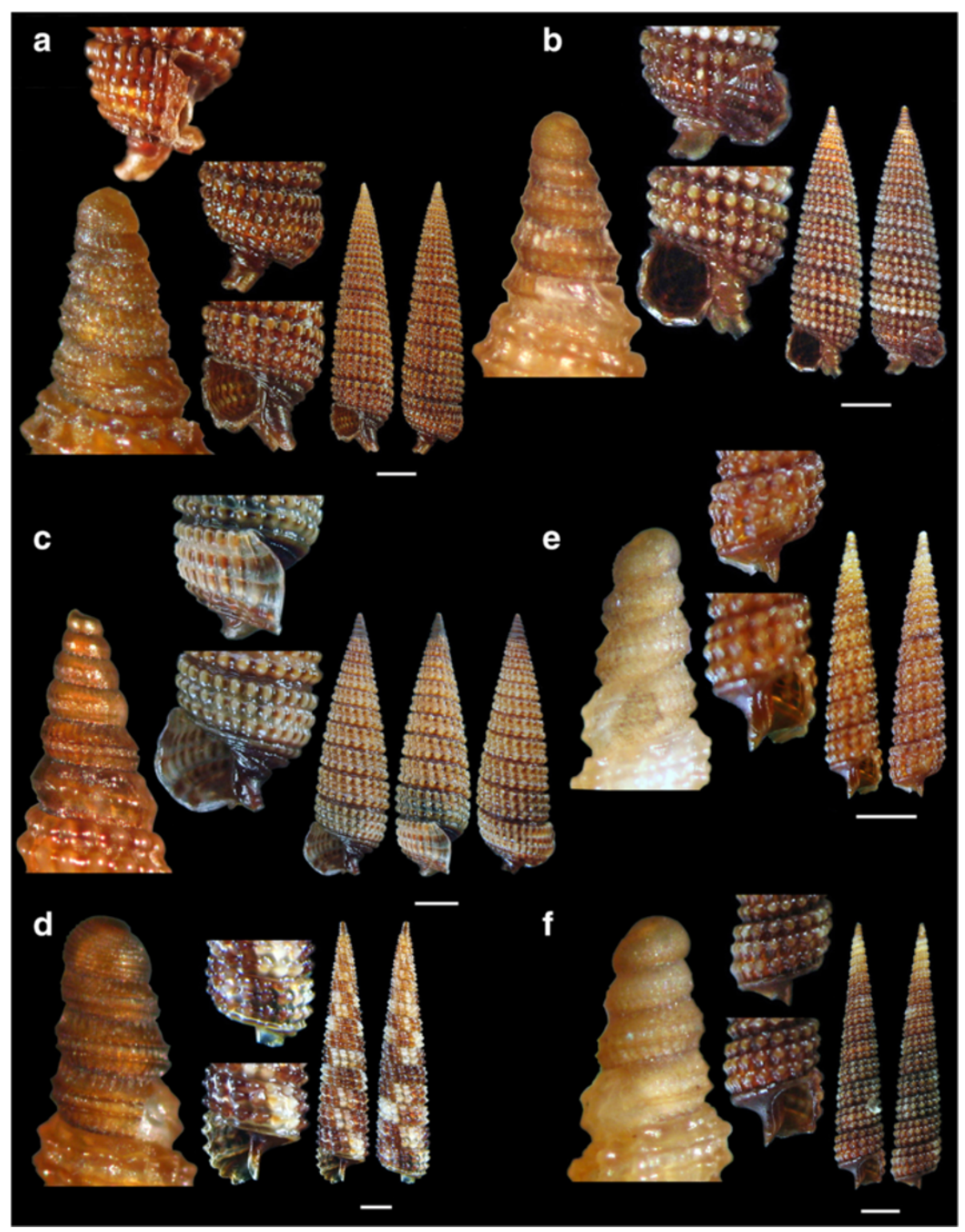

Figure 4 The new recorded species of the families Triphoridae: a. Monophorus thiriotae, b. Obesula marinostri, c. Similiphora triclotae, d. Strobiligera flammulata, and Cerithiopsidae: e and f. Cerithiopsis atalaya. Bar $=1 \mathrm{~mm}$.

therefore the more depressed profile and the much wider umbilical region [27].

Habitat and distribution West Mediterranean Sea [21] up to the northern part of the Central Mediterranean Sea [27].

Status Less frequent [21] to common [27].

\section{Phasianellidae}

Tricolia deschampsi Gofas, 1993 (Figure 3a).
Collection station One shell $(0.65 \mathrm{~mm}$ long, $0.65 \mathrm{~mm}$ wide) was found in detritus material from mixed bottom of station 15 .

Description The shell has over two whorls and a low spire with an ample body whorl. Its protoconch consists of nearly one whorl, is nearly $90 \mu \mathrm{m}$ wide and with a strong sculpture decoration. The first quarter of a whorl of the teleoconch bears a spiral microsculpture of 6-7 spiral cords, narrower than the interspaces, gradually replaced on later whorls by spiral rows of small punctures. Umbilical chink narrow, bordered by a sharp and white keel. The aperture is broad and rounded. The protoconch 


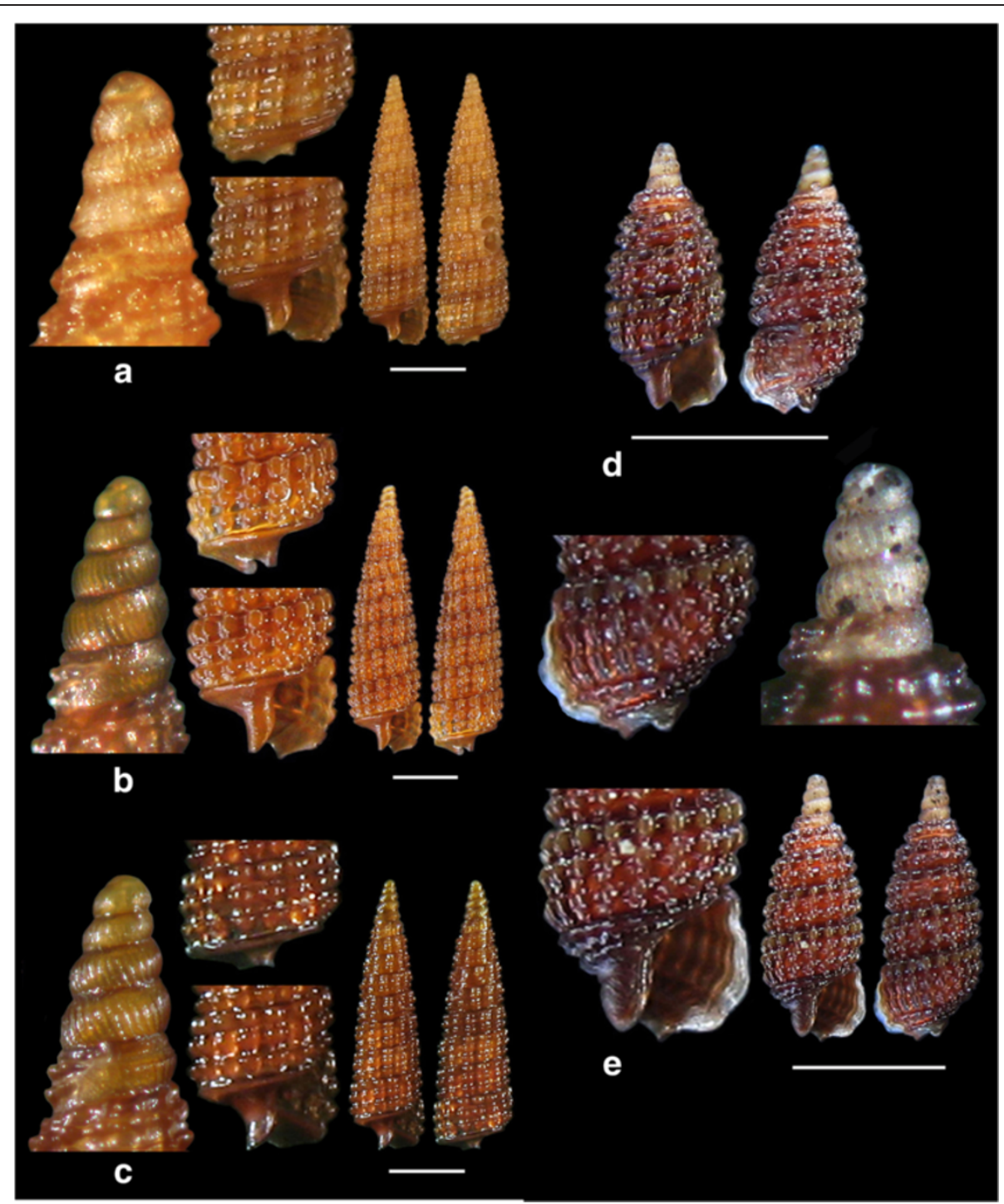

Figure 5 The new recorded species of the family Cerithiopsidae: a. Cerithiopsis diadema, b and c. Cerithiopsis fayalensis, $\mathrm{d}$ and e. Cerithiopsis micalii.

is opaque white. The first quarter of a whorl of the teleoconch is also white and the rest with pink, narrow and sharp lines arranged parallel to the growth lines and opaque white anastomosing lines on a translucent background. The periumbilical area exhibits a wavy contour of alternating pink and white patches.

Similar species With slightly smaller dimensions, this species is morphologically similar to the congeneric Tricolia tingitana with which it shares the same shape of the umbilicus but has a different color pattern [28]. T. deschampsi is also similar to T. entomocheila but the late is different in the color pattern and its direction, the shell's outline and its protoconch lacks the sculptural decoration present in our specimen. Moreover the specimen is dissimilar to T. pullus because of the color pattern, the shell's outline and because T. pullus protoconch lacks a sculptural decoration [28].

Habitat and distribution Lives in the infralitoral zone $(<40 \mathrm{~m})$ between photophilic algae [28,29]. Species originally known from the area of the Strait of Gibraltar but subsequently collected in several other locations in the Mediterranean [27-29].

\section{Status Uncommon [27].}

\section{Siliquariidae}

Petalopoma elisabettae Schiaparelli, 2002 (Figures 3b, $\mathrm{c}, \mathrm{d}$ and $\mathrm{e})$. 


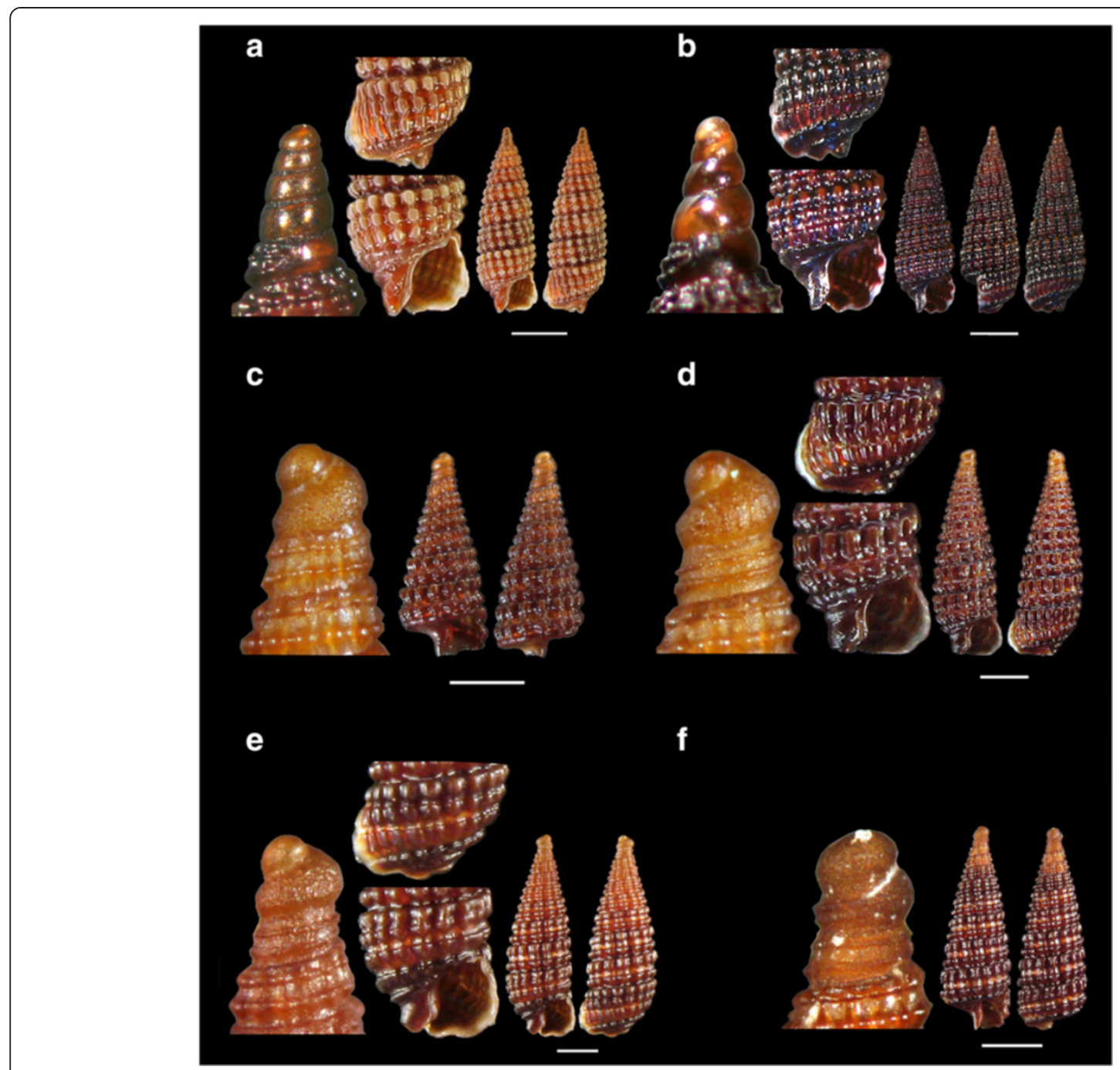

Figure 6 The new recorded species of the family Cerithiopsidae: a. Cerithiopsis nana, b. Cerithiopsis cf. oculisfictis, c, d, e and f. Dizoniopsis concatenata. Bar $=1 \mathrm{~mm}$.

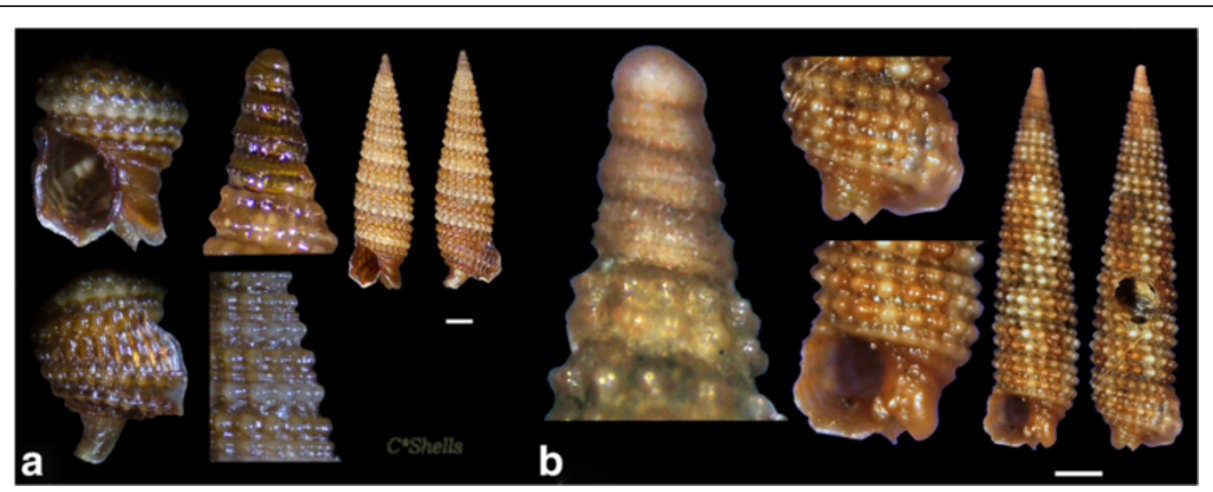

Figure 7 Additional samples collected and photographed by C. Kontadakis: a. Obesula marisnostri and G. Mpazios: b. Strobiligera flammulata. Scale bars $=1 \mathrm{~mm}$. 
Collection station Two juvenile shells $(2.00 \mathrm{~mm}$ and $5.00 \mathrm{~mm}$ long, $0.70 \mathrm{~mm}$ and $1.60 \mathrm{~mm}$ wide, respectively) were found in detritus material trapped in small scale fishing nets at $10 \mathrm{~m}$ depth from mixed bottom of station 1. One live individual (9.60 $\mathrm{mm}$ long, $0.30 \mathrm{~mm}$ wide) still with its operculum and three shells $(7.10 \mathrm{~mm}$ long, $0.20 \mathrm{~mm}$ wide; $11.15 \mathrm{~mm}$ long, $2.90 \mathrm{~mm}$ wide; $14.00 \mathrm{~mm}$ long, $2.90 \mathrm{~mm}$ wide) were trawled trapped in a piece of sponge from $70 \mathrm{~m}$ at station 4 . One shell $(4.00 \mathrm{~mm}$ long, $1.30 \mathrm{~mm}$ wide) was found in detritus material trapped in small scale fishing nets at $30 \mathrm{~m}$ depth from mixed bottom of station 15 .

Description The shell-shaped tubes (characteristic feature of the family) are small and slender, some with an intact lecithotrophic white protoconch and with a side slit of irregular width. The shell bears very irregular and alternating narrow and wider zones. The general outlook of the shell resembles the tip of a spear. The color is light cream-yellow to light cream-pink still retaining in places a brown periostracum.

Similar species Very similar in its general outlook to Tenagodus obtusus (Schumacher, 1817) from which it differs in its smaller size, its more slender and wiry tube (T. obtusus is more depressed and hunched over with the first few laps forming a regular spiral and then taking a variable form), its lecithotrophic protoconch (in contrast to the planktotrophic one of T. obtusus), its more irregular in width side slot (in T. obtusus it is of a constant width), the alternating narrower and wider zones in the total length of the tube and in its cream color (in contrast to the brown of T. obtusus). Petalopoma elizabetae seems to be strongly associated with sponges upon which it feeds while T. obtusus lives attached to rocks [30].

Habitat and distribution It has been found live in sponges from 20 to $40 \mathrm{~m}$ of depth in the Central Mediterranean Sea [30] and the W Mediterranean Sea [22].

Status Rare [27].

\section{Triphoridae}

Monophorus thiriotae Bouchet, 1985 (Figure 4a).

Collection station Two live individuals $(7.15 \mathrm{~mm}$ and $6.85 \mathrm{~mm}$ in length, $1.65 \mathrm{~mm}$ and $1.55 \mathrm{~mm}$ wide, respectively) and one immature shell $(8.95 \mathrm{~mm}$ in length, $1.95 \mathrm{~mm}$ wide) were collected from detritus material trapped in small scale fishing nets at $70 \mathrm{~m}$ depth from mixed bottom of station 4 . One shell $(8.80 \mathrm{~mm}$ in length, $1.90 \mathrm{~mm}$ wide) was collected from detritus material trapped in small scale fishing nets at $30 \mathrm{~m}$ depth from mixed bottom of station 15 .

Description The rather slender sinistral shell has a high and regularly conical spire. Its protoconch is pointed, with $43 / 4$ moderately convex whorls. The embryonic part is decorated with little tubercules that give the appearance of a reticulated sculpture all over its surface, while the larval part bears two strong carinas that are narrower than their interspace, and axial slightly sigmoid riblets. The teleoconch has 12 almost flat whorls. The sculpture consists of smooth and rounded pearl-like tubercules that are much wider than the interspaces and are aligned axially. In the first whorl of the teleoconch there are two cords, with one third sandwiched in between them much later and increasing in thickness, without becoming equally thick with the others until the last whorl. The last whorl narrows sharply at its base and bears one more granular cord (4th) in prolongation of the suture and two others (the 5th is rough and the 6th slightly wavy) between that and the siphonal canal. In the final part of the last whorl and in the vicinity of the outer lip, the four uppermost cords are not divided into additional cords but simply become flatter. The aperture has an expanded simple outer lip with a fragile edge. The siphonal canal is short, almost closed forming a conical projection and the upper part of the aperture has a deep notch near the suture. The chestnut brown color is lighter on the tubercules while the interspaces are darker.

Similar species Monophorus thiriotae is quite similar to other members of the family. It differs from the congeneric M. erythrosoma (Bouchet \& Guillemot, 1978) by not being monochromatic and by the spiral cords not dividing before the end of the spire [31], from Cheirodonta palescens (Jeffreys, 1867) by having cords not subdivided on its outer lip and from Marshallora adversa (Montagu, 1803) by being plumper and a bit bigger. It also differs from Cheirodonta, Marshallora, and Similiphora in that its additional cords of the last whorl are granular [22].

Habitat and distribution In infralittoral rocky bottoms on sponges. Atlantic coast of Europe from the Basque Country to Morocco, the Canary Islands, the Azores and the W Mediterranean Sea [22].

Status Uncommon in the W Mediterranean [27]. Obesula marisnostri Bouchet, 1985 (Figure 4b).

Collection station One live individual $(5.50 \mathrm{~mm}$ in length, $1.50 \mathrm{~mm}$ wide) was collected from detritus material trapped in small scale fishing nets at $20 \mathrm{~m}$ depth from mixed bottom of station 1. One more (second) 
record by the collector Mr. Costantinos Kontadakis from $\mathrm{S}$ Greece is discussed in the relevant section.

Description The sinistral shell has a high and regularly conical spire. The protoconch is formed by four moderately convex whorls, the first of which is covered with tiny granules and followed by numerous axial ribs interrupted by a single keel up to the beginning of the teleoconch. The late is formed by 10 almost flat whorls separated by a deep suture which is highlighted in relation to the interspaces between the spiral cords. The sculpture consists of spiral cords wider than the interspaces and formed by smooth and rounded pearl-like tubercules which are aligned axially. In the first whorl of the teleoconch there are only two cords, with a third one sandwiched in between them from the fourth whorl and growing rapidly to become of even thickness with the two others. The last whorl is tapered at its base, with an additional granular cord in prolongation of the suture and two more cords between that fourth cord and the siphonal canal. Aperture with a simple, somewhat expanded outer lip and a deep notch near the suture. A thick siphonal canal opened only by a narrow slit and forming a conical projection. The shell is pale chestnut in color, with slightly darker the protoconch, the adapical part of the teleoconch and the tip of the siphonal canal and with slightly lighter the pearls of the third cord.

Similar species This species is very easily recognized by the single keel on the protoconch and the two additional granulated cords in the last whorl, in contrast to the smooth or slightly wrinkled ones of the other species [22].

Habitat and distribution In funds between $30 \mathrm{~m}$ and $200 \mathrm{~m}$ of the circalittoral gravel floor of the Atlantic and the Western Mediterranean from the Alboran Sea to Italy, France and Algeria [27].

Status Uncommon in the W Mediterranean Sea [22,27]. Similiphora triclotae (Bouchet, 1996) (Figure 4c).

Collection station Two live individuals $(6.80 \mathrm{~mm}$ and $5.00 \mathrm{~mm}$ in length, $2.10 \mathrm{~mm}$ and $1.70 \mathrm{~mm}$ wide, respectively) and two shells $(8.00 \mathrm{~mm}$ and $5.00 \mathrm{~mm}$ in length, $2.55 \mathrm{~mm}$ and $2.10 \mathrm{~mm}$ wide, respectively) were collected from detritus material trapped in small scale fishing nets at $40 \mathrm{~m}$ depth from mixed bottom of station 2 .

Description The sinistral shell has a high and regularly conical spire. The protoconch is pointed, with five moderately convex whorls, the first of which is covered with tiny granules, while the rest ones with numerous axial riblets. In its second whorl there is only one spiral keel and in the following whorls two keels narrower than their interspace. The more or less slender teleoconch consists of 11 almost flat whorls. The sculpture consists of spiral cords wider than the interspaces and formed by smooth and rounded pearl-like tubercules which are aligned axially. In the first round of the teleoconch there are only two cords with a third appearing in between them from the sixth whorl and then increasing in thickness. The last whorl narrows sharply at its base with an initially slightly wrinkled cord and subsequently beaded cord in the prolongation of the suture and two more cords between that and the siphonal canal. The aperture bears a simple, somewhat expanded external lip with fragile edge and a deep notch by the suture. The cords by the end of the spire do not divide. The siphonal canal is short, almost closed and forming a conical projection. Very deep chestnut-brown background color all over the shell including the protoconch and its adapical part and much lighter to pale yellowish pearls. The animal had white and translucent tentacules.

Similar species Similiphora triclotae has a smaller and more slender shell than Marshallora adversa (Montagu, 1803), is very similar to S. similior (Bouchet \& Guillemot, 1978) from which it differs in the white tentacules of the animal in contrast to the black foot and the black line on the tentacles of S. similior and from both $M$. adversa and S. similior in its pale-yellowish pearls against a dark chestnut-brown background [22].

Habitat and distribution In infralittoral rocky bottoms on sponges. Only known from the Strait of Gibraltar and Southern Portugal [22,27].

\section{Status Rare [22].}

Strobiligera flammulata Bouchet \& Waren, 1993 (Figure 4d).

Collection station One live individual $(8.00 \mathrm{~mm}$ in length, $1.55 \mathrm{~mm}$ wide) and a juvenile shell $(3.05 \mathrm{~mm}$ in length, $1.00 \mathrm{~mm}$ wide) were collected from detritus material trapped in small scale fishing nets at $120 \mathrm{~m}$ depth from mixed bottom of station 14 and at $30 \mathrm{~m}$ from mixed bottom of station 15, respectively. One more (first) record by the collector Mr. G. Mpazios from S Greece is discussed in the relevant section.

Description The very slender sinistral shell has a high and regularly conical spire. The pointed protoconch bears four very convex whorls, the first of which is covered with tiny intersecting lines while the last two whorls bear a double keel the cords of which are narrower than the interspace and are crossed by numerous, irregular and fine axial riblets. The teleoconch bears 16 almost flat whorls separated by a shallow suture which is 
difficult to distinguish from the spaces between the cords. The sculpture costists of spiral cords the interspaces of which are much wider than their pointed tubercules which are aligned but not attached axially. At the onset of the teleoconch there are only two cords with a third cord appearing bellow the suture from the fourth whorl and then increasing in thickness. The last whorl bears an additional wrinkled cord in prolongation of the suture. Aperture with a simple lip, a straight columella and a short siphonal canal. Color of randomly arranged alternating cream-white and chestnut-brown areas covering sections of the shell but without conforming to its sculpture.

Similar species The species is easily differentiated from the other European Triforids as its first cord of the teleoconch appears on the top of the other two instead of in-between those [22,27].

Habitat and distribution In circalittoral rocky bottoms. Atlantic and W and SW Mediterranean Sea [22,27].

Status Rare [22,27].

\section{Cerithiopsidae}

Cerithiopsis atalaya Watson, 1885 (Figures 4e and f).

Collection station Two shells $(6.90 \mathrm{~mm}$ and $6.45 \mathrm{~mm}$ in length, $1.35 \mathrm{~mm}$ and $1.25 \mathrm{~mm}$ wide, respectively) were collected from detritus material trapped in small scale fishing nets at $70 \mathrm{~m}$ depth from mixed bottom of station 4, and three shells (5.90, 4.95 and $4.50 \mathrm{~mm}$ long, $1.15,0.95$ and $0.85 \mathrm{~mm}$ wide, respectively) also from detritus material trapped in small scale fishing nets at $25 \mathrm{~m}$ from mixed bottom at station 15 .

Description The shell has a high and regularly conical slender spire. The pointed protoconch bears four highly convex whorls with sculpture formed by two prominent and narrow keels positioned in the middle of the whorls and axial ribs crossed by even thinner, slightly prosocline, ones that extend from suture to suture. The teleoconch bears 14 almost straight whorls, with axial ribs and spiral cords forming cross-shaped pearls in their intersection with the ribs. The first three whorls show two cords with a third one appearing gradually under the suture and progressively increasing in thickness to become equivalent in width to the two others by the last whorl. The pearls of the cords are acute and give the sculpture a rough appearance. The last whorl bears at its base a fourth, more or less, smooth cord below the suture and forms a somewhat concave smooth base. The square aperture has a straight columella, a short siphonal canal and a simple outer lip. The shell exhibits an uneven chestnut-brown color, lighter to yellowish in the first whorls of the teleoconch and in some parts of the later whorls.

Similar species Cerithiopsis atalaya is very similar to C. horrida Monterosato, 1874 from which it differs in that the late is generally larger, its protoconch exhibits a less dense sculpture, the fourth cord of the last whorl is beaded and the pearls are pointed upwards creating a more rough than C. atalaya appearance [22].

Habitat and distribution In deep rocky bottoms between $80 \mathrm{~m}$ and $200 \mathrm{~m}$. Atlantic and SW Mediterranean [22].

\section{Status Uncommon [27]. Cerithiopsis diadema Monterosato, 1874 (Figure 5a).}

Collection station One shell $(3.50 \mathrm{~mm}$ in length, $0.90 \mathrm{~mm}$ wide) was collected from biogenic material trapped in small scale fishing nets at $60 \mathrm{~m}$ depth from mixed bottom of station 14 .

Description Shell with high and regularly conical spire. The pointed protoconch is formed by four moderately convex whorls, the first of which bears only very fine spiral striae that extent to the rest three whorls. In addition to that sculptural decoration, these late three whorls are decorated with numerous, somewhat curved, fine axial ribs that extend from suture to suture and are interrupted by a carina which bears a thin spiral cord up to the end of the protoconch. The teleoconch has 10 slightly convex whorls and a fairly deep suture. The sculpture is made up initially of two spiral cords, but from the fourth whorl of the teleoconch a third cord appears just below the suture and increases in width to become equally wide with the other two cords by the last whorl. The cords are approximately of equal width as the interspaces, with smooth and rather flat tubercules that are aligned axially to form ribs. The last whorl diminishes sharply in width by its base and exhibits an additional rather smooth cord in prolongation of the suture. In the proximity of that cord there is a smoother one preceeding a concave area before a short siphonal canal. Light honey color all over the shell including the protoconch.

Similar species The very characteristic protoconch in combination with the rest of the shells characteristics separate the species from the superficially similar congeneric and sympatric C. atalaya Watson, 1885, C. fayalensis Watson, 1885 and C. horrida Monterosato, 1874 [22,29].

Habitat and distribution In circalittoral rocky funds of the Atlantic and the $\mathrm{W}$ and Central Mediterranean Sea $[22,27]$. 
Status Uncommon according to Repetto et al. [27] and common based on Gofas et al. [28].

Cerithiopsis fayalensis Watson, 1886 (Figures 5b and c).

Collection station One live individual $(3.50 \mathrm{~mm}$ in length, $0.90 \mathrm{~mm}$ wide) and one shell $(3.30 \mathrm{~mm}$ in length, $0.85 \mathrm{~mm}$ wide) were collected from detritus material trapped in small scale fishing nets at $60 \mathrm{~m}$ and $120 \mathrm{~m}$ depth, respectively, from mixed bottom of station 14 and two shells (4.15 $\mathrm{mm}$ and $3.40 \mathrm{~mm}$ in length, $1.35 \mathrm{~mm}$ and $1.10 \mathrm{~mm}$ wide, respectively) were also collected from detritus material trapped in small scale fishing nets at $20 \mathrm{~m}$ depth from mixed bottom of station 1 .

Description Shell with high and regularly conical spire. The pointed protoconch is formed by five moderately convex whorls decorated with numerous, somewhat curved, fine axial riblets that extend from suture to suture; these riblets are overlaid by an extremely thin and hard to see spiral sculpture. The teleoconch has 8 almost flat whorls with a fairly deep suture. Sculpture made up of three spiral cords, slightly wider than the interspaces, with smooth and rounded tubercules that are aligned axially to form ribs. In the first whorl of the teleoconch, the adapical cord (lower one) is much weaker than the two cords above, then increases in thickness but only in the last whorl it becomes as thick as those two. The last whorl exhibits an additional smooth cord in prolongation of the suture and a smooth concave area between that cord and the short siphonal canal. Light brown to medium-brown color all over the shell including its protoconch.

Similar species The very characteristic protoconch in combination with the rest of the shells characteristics separate the species from the superficially similar congeneric and sympatric C. atalaya, C. horrida and C. scalaris [22].

Habitat and distribution In circalittoral rocky funds, exceptionally at $30 \mathrm{~m}$, but principally at $100 \mathrm{~m}$ to $300 \mathrm{~m}$, in Atlantic and the W Mediterranean Sea as well as the Ionian Sea [22,27].

Status Uncommon [22].

Cerithiopsis micalii (Cecalupo \& Villari, 1997) (Figures 5d and e).

Collection station One live individual $(1.75 \mathrm{~mm}$ in length, $0.70 \mathrm{~mm}$ wide) and a shell $(1.45 \mathrm{~mm}$ in length, $0.60 \mathrm{~mm}$ wide) were collected from detritus material trapped in small scale fishing nets at $70 \mathrm{~m}$ depth from mixed bottom of station 4 .
Description Shell with cirtoconoid "obese" spire. Protoconch ivory-white, styliform, with four moderately convex whorls bearing flexural axial ribs. Teleoconch with five whorls and a deep suture. Sculpture consisting of tree spiral cords, only two in the first whorl of the teleoconch with a third one formed below the suture and increasing in width in the following whorls. The last whorl which narrows towards its base bears a wrinkled cord as a continuation of the suture and an additional very prominent and also wrinkled one before the siphonal canal. The outer lip of the aperture is simple, fragile and white in contrast to the rest of the teleoconch which is of bright red-brown color.

Similar species Cerithiopsis micalii has a very similar sculpture and configuration of its last whorl with that of C. tubercularis (Montagu, 1803) but is different from the late in the shape of its teleoconch and its characteristic protoconch [22].

Habitat and distribution In infralittoral rocky bottoms, presumably on sponges. Atlantic and Mediterranean Sea but only known from a few locations of its western basin $[22,27]$.

Status Rare [22] and uncommon [27].

Cerithiopsis nana Jeffreys, 1867 (Figure 6a).

Collection station One live individual $(4.05 \mathrm{~mm}$ in length, $1.25 \mathrm{~mm}$ wide) was collected from detritus material trawled at $100 \mathrm{~m}$ depth from mixed bottom of station 4 , and one shell (3.35 $\mathrm{mm}$ in length, $1.05 \mathrm{~mm}$ wide) was collected from detritus material trapped in small scale fishing nets at $50 \mathrm{~m}$ depth from mixed bottom of station 15 .

Description Shell with a cirtoconoid spire. The protoconch consists of four slightly convex whorls that form a blunt apex. Just below its suture there is a series of tiny elongated nodules while just over it there is an additional series of nodules forming a very thin cord. The three adapical whorls form a weak carina at their lower part. The teleoconch consists of seven slightly convex whorls. The sculpture is made up of three spiral cords and two more in the last whorl bellow the suture. The upper cord on the spire is weaker than the medium cord and stuck to it, gradually increasing in width and distancing away until by the last whorl it becomes the wider cord. The last whorl narrows at its base, with an extra grainy cord in prolongation of the suture and another one between that and the siphonal canal. The aperture bears a simple, fragile and white outer lip. Light brown color on the protoconch, cinnamon-brown on the spire 
with brighter the pearls and the additional cords of the base.

Similar species Cerithiopsis nana is quite similar to Cerithiopsis tubercularis (Montagu, 1803) from which it differs in its smaller size, its blunter protoconch and the additional fine cord of tiny nodules over the suture, not present in C. tubercularis [22].

Habitat and distribution In infralittoral rocky bottoms on sponges. Atlantic and Mediterranean Sea [22].

Status Uncommon [27].

Cerithiopsis cf. oculisfictis Prkic \& Mariottini, 2010 (Figure 6b).

Collection station Two live individuals $(4.05 \mathrm{~mm}$ and $4.00 \mathrm{~mm}$ in length, $1.15 \mathrm{~mm}$ and $1.10 \mathrm{~mm}$ wide, respectively) were collected from detritus material trawled at $100 \mathrm{~m}$ depth from mixed bottom of station 4 .

Description The small shell has L/D (length/max diameter) ratio of 3.50 , is conical, glossy and slightly scalaroid. Its also conical protoconch (460 $\mu \mathrm{m}$ high, $255 \mu \mathrm{m}$ wide) is smooth, chocolate-brown in color, semi-transparent, with nearly 4.5 convex whorls and a suture bearing a series of tiny nodules forming a very thin cord. The teleoconch consists of eight, nearly flat, whorls. Its spiral sculpture is composed of three cords made of series of smooth pearls. The adapical cord is initially weaker than the two lower ones but eventually grows equally strong in the last four whorls to become the dominant cord that gives the shell its scalaroid outlook and is distant from the median cord. The body whorl narrows smoothly at its base, with an extra wavy cord in prolongation of the suture and another one between that and the siphonal canal. This last whorl is decorated with 21 ribs weaker than the spiral cords and giving rise to equidistant conspicuous nodules. These nodules become axially ovate on the last three whorls. The suture is deep leading the whorls to be well separated from each other. Aperture subquadrangular, smooth and wide. Outer lip simple, thin, orthocline and white. Columellar callus weak. Anal canal broad and short, siphonal canal open and short. Viewed through the aperture, transparency makes visible the sculptural pattern of the spire. Chocolate-brown color on the protoconch, the background of the teleoconch and the base with brighter pearls on the spire. The animal, that quickly withdrew itself into the shell, had a white foot and a dark grey head.

Similar species Cerithiopsis cf. oculisfictis is quite similar to Nanopsis nana from which it differs in that the protoconch of $C$. cf. oculisfictis bears more convex whorls that lack the weak carina of $N$. nana, the upper cord on the spire is strong in contrast to the weak of $N$. nana and the color is chocolate-brown in contrast to the light brown of N. nana [22]. Cerithiopsis cf. oculisfictis is also similar C. tubercularis (Montagu, 1803) from which it differs in that the late has a more slender shell; its protoconch whorls bear a very fine spiral thread just above the suture as well as short axial riblets; the columellar callus is well marked and conspicuously elevated and the propodium is gray to black [32].

Habitat and distribution From the intertidal to the upper sublittoral zones $(0-8 \mathrm{~m})$, associated to small sponges and known only from certain localities along the Dalmatian coast, North Adriatic Sea [32].

Status Cerithiopsis oculisfictis is a recently described species and is rather common in the N Adriatic Sea [32].

Dizoniopsis concatenata (Conti, 1864) (Figures 6c,d, e and $f$ ).

Collection station Three live individuals $(4.35 \mathrm{~mm}$ to $3.00 \mathrm{~mm}$ in length, $1.45 \mathrm{~mm}$ to $1.00 \mathrm{~mm}$ wide) and 3 shells $(4.00 \mathrm{~mm}$ to $2.50 \mathrm{~mm}$ in length, $1.35 \mathrm{~mm}$ to $0.90 \mathrm{~mm}$ wide) were collected from detritus material trapped in small scale fishing nets at $25 \mathrm{~m}$ depth from mixed bottom of station 1. Two shells (3.45 and $2.10 \mathrm{~mm}$ in length, 1.15 and $0.70 \mathrm{~mm}$ wide, respectively) were collected from detritus material trapped in small scale fishing nets at $30 \mathrm{~m}$ depth from mixed bottom of station 15 .

Description The conical, slightly cyrtoconoid shell has a protoconch with something more than two whorls the first of which is rough with or without minor dotty axial ribs, is globose, narrowing sharply to continue with the second whorl which, in turn, bears on its middle part two close to each other spiral keels. The teleoconch consists of eight almost flat whorls. The sculpture is formed by two cords of about the same width as the interspaces, with rounded pearl-like tubercules. The cord bellow the suture shows pearls with a tendency to widen axially forming elongated tubercules that finally divide as they approach the outer edge of the aperture (concatenata). The last whorl narrows at its base and bears two extra cords, a grainy one in prolongation of the suture and a smooth narrower one between the grainy one and the siphonal canal. The outer lip of the aperture is simple, fragile, flairy and white in contrast to the vivid chestnutred color of the rest of the shell, which becomes paler towards the shells apex.

Similar species Dizoniopsis concatenata is quite similar to D. coppolae (Aradas, 1870) from which it differs in its characteristic protoconch, the dividing pearls of its 
upper cord by the aperture and by having two additional cords on its last whorl (instead of three in D. coppolae). Dizoniopsis clarkii (Forbes \& Hanley, 1848) and D. bilineata (Hornes, 1848) are erroneous identifications [22].

Habitat and distribution In infralittoral rocky floors, of unknown with precision hosts and quite often collected live [22]. Known from the Atlantic and the E Mediterranean Sea [22,27].

\section{Status Uncommon [22].}

\section{Discussion}

Among the 37 identified species, 16 are referred for the first time for the Hellenic fauna raising its gastropod biodiversity from 631 species [19] and additions by Manousis et al. [17] to 651. One more new alien new species of the genus Emarginula originated from the Indian Ocean is recorded in the Mediterranean Sea thus enriching significanty (20\%) the members of the family Fissurellidae in Greece. Five genera of different families are new for the Hellenic fauna (see Table 1).

The current enrichment of the studied families in the NW Aegean with 16 new species for Greece (with the vast majority of them being minute in size and collected from hard biogenic substrates), 14 of which are new for the E Mediterranean Sea and one of them being new for the Mediterranean Sea, was expected to take place. It is attributed to i) the few and, in some cases, old studies on the gastropod fauna of the area, ii) the lack of search in various environments as far as the different depths and the types of substrate is concerned iii) the collection tactics related to the type of habitats, to all possible and available material and substrate sources (e.g. discarded material from the fishing boats), to the collection equipment, to the detailed sorting of minute in size organisms and to the repeated search efforts and iv) study areas with variable substrates and clean marine environment promise a rich biodiversity.

Anatoma aspera (Philippi, 1844) - one of the small and fragile members of the genus Anatoma - has been reported by Geiger [26] for the first time from the $\mathrm{S}$ Aegean Sea and Sporades in coordinates of $\sim 36^{\circ} \mathrm{N}$, $27^{\circ} \mathrm{E}$ (most probably he means South Sporades - the old name of the Dodecanese - because the coordinates of the name that he uses "Sporades" are $\sim 39^{\circ} \mathrm{N}, 24^{\circ} \mathrm{E}$ and is located in the $\mathrm{N}$ Aegean Sea). The finding of the newly described minute species of Anatoma micalli reveals, apart from the research gaps, the identification difficulties on the Anatoma species, attributed to numerous misidentifications, the various chresonyms and synonyms mainly of the species A. aspera, A. micalii and A. umbilicata [26] and the lack of useful tools for identification, such as publications with full descriptions and comparisons of the species, and the shortage of detailed and high quality images.

After the collection of Obesula marisnostri specimen during this study, three more live individuals and a shell (7.75 to $5.05 \mathrm{~mm}$ in length, 2.30 to $1.50 \mathrm{~mm}$ wide) (Figure 7a) were collected by the collector Constantinos Kontadakis from biogenic material trapped in small scale fishing nets at 60-100 m depth from mixed bottom of Central Saronikos Gulf (S Greece). The specimen of Strobiligera flammulata of this study was collected one month later (26 June 2013) after (26 May 2013) the collector George Mpazios collected one shell ( $8.90 \mathrm{~mm}$ in length, $1.95 \mathrm{~mm}$ wide) (Figure $7 \mathrm{~b}$ ) from biogenic material trapped in small scale fishing nets at 80-120 m depth from mixed bottom of SW Saronikos Gulf by Epidaurus ( $\left.37^{\circ} 38.000^{\prime} \mathrm{N}, 23^{\circ} 11.500^{\prime} \mathrm{E}\right)$. The almost simultaneous findings of Obesula marisnostri and Strobiligera flammulata both from N and S Greece indicates that i) they are wider distributed in the Hellenic Seas and the Eastern Mediterranean Sea, ii) independent searches from the same type of substrates (e.g. biogenic bottom) and direct sampling might bring to light more species that could otherwise be lost during the fishing procedure and handling and iii) the potential source of information on biodiversity issues through the use of appropriate fora).

The unexpected and simultaneous finding of two live individuals very similar to the species Cerithiopsis oculisfictis did not give us the time to examine in detail the color pattern of the living animal and look for the two (characteristic for the species) black spots on the propodium [32], and, therefore, their identification has to remain as $C$. cf. oculisfictis. Moreover, at the species level, the color pattern of the head-foot (propodium) comprises a diagnostic feature in the Cerithiopsis tubercularis complex [33].

Among the new findings, Emarginula decorata - referred from SE Africa [23], the Reunion Islands, Red Sea and the Arabian Gulf [21] - is a new alien mollusc species for the Mediterranean Sea added to the already recorded 215 ones by 2012 [34]. The dispersal of such a benthic organism is attributed to biological (endogenic) and environmental (exogenic) parameters. More specifically, among the biological parameters, the potential migration of a gastropod species in the form of teleplanic larvae could be a result of i) the larvae "escape" degree from the "parent area", ii) their survival as meroplankton and iii) the chance for reproduction as adults in the new environment [35]. As far as the environment itself is concerned, the parameters include human activities and their effects on the dispersal of the larvae (directly by means of currents and ships and indirectly by means of aquacultures) and the juveniles/adults ratio (directly by means of aquacultures and indirectly by means of transportation as epibenthic/epibionts). Nevertheless, the climate changes in 
the Mediterranean Sea and the almost 1000 different alien species recorded by 2012 [34] have particularly changed the biodiversity during the last two or three decades having as a result the publication of numerous articles in which the reasons for occurrence of aliens in the Mediterranean Sea, the frequency of the records, the vectors and the distribution pathways have been extensively discussed (e.g. [34,36-41]).

More than half (54\%) of the marine alien species in the Mediterranean have, most probably, entered the area through "corridors" such as - and mainly - the Suez Canal. Shipping is directly connected with the introduction of only 12 species, whereas it is indirectly assumed as being the most probable way for the introduction (via ballasts or fouling) of another 300 species [34]. The alien species Emarginula decorata recorded from Siggitikos
Gulf indicate that its possible vector is the sea currents rather than the limited navigation in that area. Suez Canal is one of the most significant hot points for alien dispersal to the East and the West [41]. Following the sea currents model in the Mediterranean Sea, the eastern current direction is correlated with the northward progressive dispersal of the Lessepsian molluscs along the coasts of Israel, Lebanon, Syria, and from there towards the southern coasts of Turkey and the coasts of Cyprus, and, finally, in-between the Greek islands of the E Aegean and the Aegean coasts of Turkey [41-45]. Taking, though, into account the directions of the sea currents in the Aegean Sea (Figure 8), the proposed by Tzomos et al. [41] corridor along the E Aegean seems to be a rather secondary one for the molluscs of deeper waters, as the main currents move parallel and along the western coasts of the

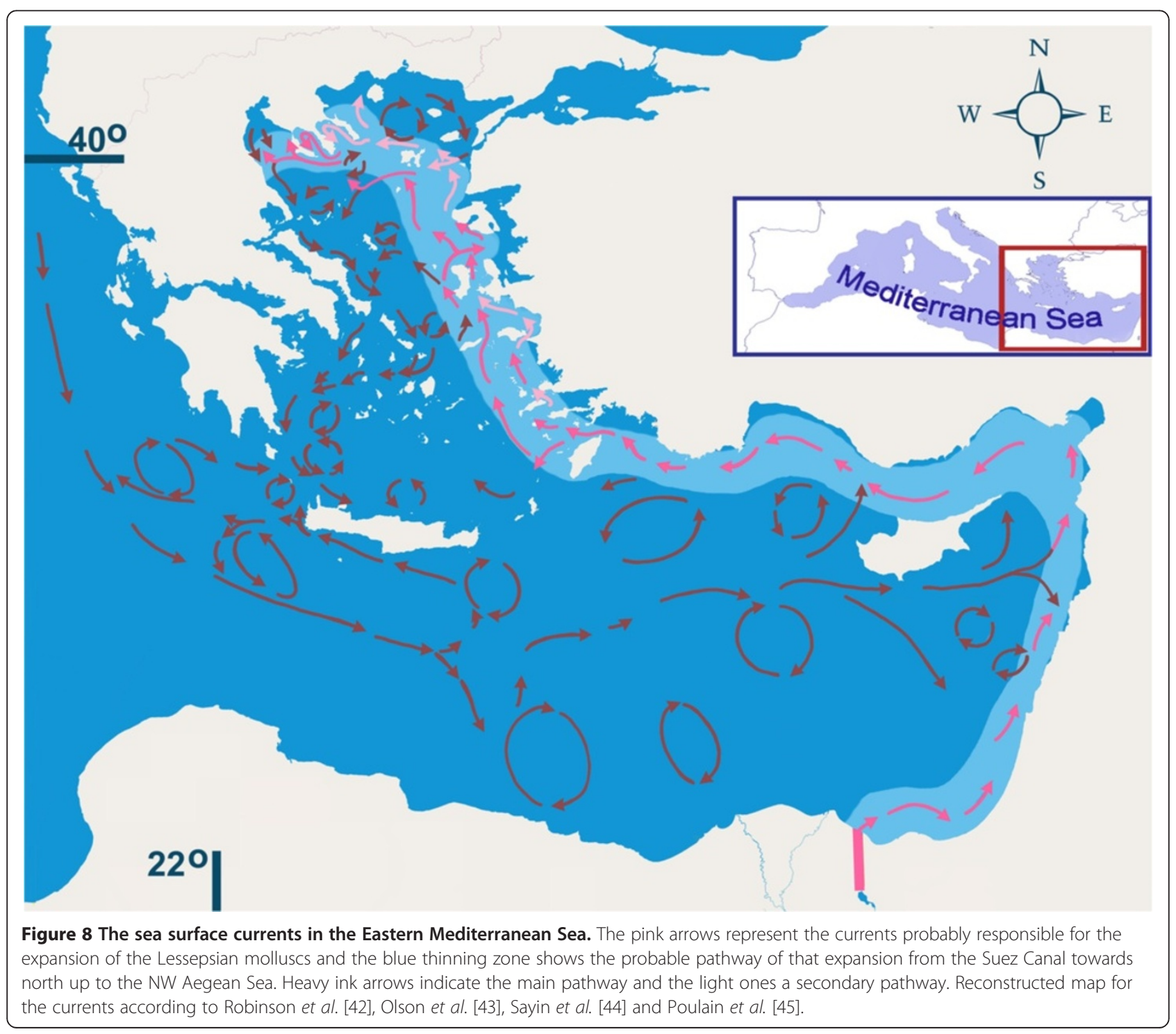


Hellenic islands of the E Aegean Sea. As these currents approach the Dardanelles and due to the Black Sea SW currents of lower salinity waters, they turn west, continue towards the NW Aegean in a pathway of the same higher salinity than that of the NE Aegean Sea, pass south of the Chalkidiki Peninsulas branch and enter Siggitikos and Toronaeos Gulfs and subsequently Thermaikos Gulf (Figure 8).

The work continues on other molluscan families and expands in more areas while collaborations between researchers and collectors could effectively improve the marine biodiversity profiles of the Hellenic Seas.

\section{Conclusions}

Thirty seven species, the majority of which is of minute size, belonging to seven families (Cerithiopsidae, Fissurellidae, Phasianellidae, Scissurellidae, Siliquariidae, Skeneidae, and Triphoridae) were identified. Among those, one (Emarginula decorata Deshayes, 1863) is a new alien for the Mediterranean Sea, 14 are new for the Eastern Mediterranean Sea and 16 are new for the Hellenic fauna with the two above mentioned alien species included. The new findings are attributed both to the sampling methods employed and the under- or unsearched marine environments as far as different types of substrates and depths are concerned. Based on the new findings of this study, the pathway of alien species distribution to the $\mathrm{N}$ and NW Aegean Sea [46] is extended up to Thermaikos Gulf.

\section{Methods}

The sampling of specimens was conducted from October 2008 to January 2014 in certain locations of Thermaikos, Toronaeos and Siggitikos Gulfs (Figure 1) by i) sieving soft bottom surface of shallow waters through a series of sieves with a mesh of $5 \mathrm{~mm}, 2 \mathrm{~mm}$ and $0.5 \mathrm{~mm}$, ii) diving down to a depth of $10 \mathrm{~m}$ of the infralittoral zone, iii) searching the supralittoral of several coasts of the Gulfs and iv) searching only fresh trawled and discarded material from small scale fishing nets taken from the vessels. That particular material from the Toronaeos Gulf was consisting mainly of biogenic substrate pieces, accompanied, in cases, by parts of maerl. After cleaning with fresh water, shells were treated with a small amount of parafine oil in acetone, left for acetone to evaporate and examined under a stereoscope with a magnification of up to $80 \times$. For each species collected, the following data have been recorded: location, depth, type of habitat/substrate and size (length, unless otherwise stated). The species recognition was based on a) systematic guides, atlases such as Delamotte \& Vardala-Theodorou [12], Gofas et al. [22], Repetto et al. [27], Poppe \& Goto [46], Giannuzzi-Savelli et al. [47], Cachia et al. [48-50], Doneddu \& Trainito [51], Cossignani \& Ardovini [52], b) faunistic and review articles (i.e. [53-55]), c) studies on the Mollusca fauna in the Hellenic seas [17,56-59].

Information from specific web sites was also taken into account (30 June 2014). More specifically, for the species nomenclature update, besides the Marine Biodiversity and Ecosystem Functioning EU Network of Excellence (MarBEF) [60] and the World Register of Marine Species (WoRMS) [23] the Taxonomic on-line Database on European Marine Mollusca (CLEMAM) [61] was used. In addition, the Ellenic Network on Aquatic Invasive Species (ELNAIS) [62] and the Marine Mediterranean Invasing Alien Species dadabase (MAMIAS) [63] were used for the alien species status in the Hellenic and Mediterranean Seas.

The specimens are deposited in the premises of the Alexander Technological Educational Institute of Thessaloniki and those of Dr. T. Manousis. Scientists are welcome to have access to the biological material at will.

\section{Competing interests}

The authors declare that they have no competing interests.

\section{Authors' contributions}

TM conceived the idea of the study, collected sea-bottom material by diving, searched for molluscs, participated in the identification of the species, processed the images and participated in the study's design and coordination and helped to draft the manuscript. SG-M collected biogenic sea-bottom material, searched for molluscs, participated in the identification of the species, designed figures and participated in the study's design and coordination and helped to draft the manuscript, supported with the bibliography sources and is the corresponding author. Both authors read and approved the final manuscript.

\section{Acknowledgements}

The authors are grateful to the two anonymous referees for their usefull contribution to improve the publication. They are also honored by Mr. Constantinos Kontadakis and Mr. George Mpazios entrusting to them the images and relevant information of their Obesula marisnostri and Strobiligera flammulata shells.

\section{Author details}

${ }^{1} \mathrm{PO}$ Box 48 K, 57500 Epanomi, Greece. ${ }^{2}$ Alexander Technological Educational Institute of Thessaloniki, Department of Fisheries \& Aquaculture Technology, 632 00, Nea Moudania, Chalkidiki, Greece.

Received: 12 March 2014 Accepted: 23 October 2014

Published: 27 November 2014

\section{References}

1. Blue Flag. [www.blueflag.org]

2. Kourafalou $\mathrm{VH}$, Barbopoulos $\mathrm{K}$ : High resolution simulations on the North Aegean Sea seasonal circulation. Ann Geophys 2003, 21:251-265.

3. Tsiaras KP, Kourafalou VH, Raitsos DE, Triantafyllou G, Petihakis G, Korres G: Inter-annual productivity variability in the North Aegean Sea: Influence of thermohaline circulation during the Eastern Mediterranean Transient. J Mar Syst 2012, 96-97:72-814.

4. Hellenic Statistical Authority (EL.STAT). [www.statistics.gr]

5. Safemed Project - Maritime traffic flows and risk analysis in the Mediterranean Sea. [www.safemedgis.org]

6. Skliris N, Sofianos SS, Gkanasos A, Axaopoulos P, Mantziafou A, Vervatis V: Long-term sea surface temperature variability in the Aegean Sea. Adv Oceanogr Limnol 2011, 2:125-139.

7. Sakellariou E: Living Mollusca of the Gulf of Thessaloniki and their contribution in stromatography. PhD thesis. University of Athens; 1957. 
8. Tenekidis N: A Sea Shell Collection from the Greek Seas. Athens: Brothers Protopapa Ltd; 1989.

9. Koutsoubas D, Koukouras A, Voultsiadou-Koukoura E: Prosobranch Mollusc fauna of the Aegean Sea: New information, checklist, distribution. Israel J Zool 1997, 43:19-54.

10. Antoniadou C, Krestenitis Y, Chintiroglou C: Structure of the "Amphioxus sand" community in Thermaikos bay (Eastern Mediterranean). Fresen Environ Bull 2004, 13:1122-1128.

11. Koulouri P, Dounas C, Arvanitidis C, Koutsoubas D, Eleftheriou A: Molluscan diversity along a Mediterranean soft bottom sublittoral ecotone. Sci Mar 2006, 70:573-583.

12. Delamotte M, Vardala-Theodorou E: Sea Shells from the Greek Seas. Kifisia: Goulandris Museum of Natural History; 2008

13. Manousis T, Mpardakis G, Zamora Silva A, Paraskevopoulos C, Manios D, Galinou-Mitsoudi S: New findings of Gastropods in the Hellenic seas with emphasis on their origin and distribution status. J Biol Res-Thessalon 2012, 18:249-264.

14. Koroneos J: Les mollusques de la Grece. Athens: Papadakis Press; 1979.

15. Streftaris N, Zenetos A: Molluscan diversity in the N. East Aegean-Greece Rapp Comm int Mer Médit 2007, 38:607.

16. Manousis T, Mpardakis G, Paraskevopoulos C, Galinou-Mitsoudi S: The Bivalvia Mollusca of Thessaloniki and Thermaikos Gulfs (North Aegean Sea, Greece) with emphasis on new species for Hellenic waters. J Biol Res-Thessalon 2010, 14:161-179.

17. Manousis T, Galinou-Mitsoudi S: New findings of Gastropods for the Hellenic Seas. Preliminary presentation. In Proceedings of the 15th Panhellenic Symposium of Ichthyologists: 10-13 October 2013. Thessaloniki; 2013, 2013:141-144.

18. Manousis T, Galinou-Mitsoudi S: New and uncommon Bivalvia Mollusca of Thermaikos Gulf (NW Aegean Sea). J Biol Res-Thessalon 2013, 20:339-366.

19. Koukouras A: Check-list of marine species from Greece. Aristotle University of Thessaloniki. Assembled in the framework of the EU FP7 PESI project. http://www.marinespecies.org/aphia.php? $p=$ sourcedetails\&id=142068.

20. NMiTA (Neogene Marine Biota of Tropical America) Todd JA: Introduction to molluscan life habits databases. http://nmita.iowa.uiowa. edu/database/mollusc/mollusclifestyles.htm

21. Hardy's Internet Guide to Marine Gastropods. http://www.gastropods.com

22. Gofas S, Moreno D, Salas C: Moluscos Marinos de Andalucía, Volume 1. Málaga: Universidad de Málaga; 2011.

23. World Register of Marine Species (WoRMS). http://www.marinespecies.org.

24. WMSDB - Worldwide Mollusc Species Data Base. www.bagniliggia.it/ WMSD/PDFFamily/FISSURELLIDAE.pdf.

25. Famille des FISSURELLIDAE Fleming, 1822. http://vieoceane.free.fr/ mollusques/Fissurellidae.htm.

26. Geiger DL: Monograph of the little slit shells, Volume 2. Santa Barbara: Santa Barbara Museum of Natural History; 2012.

27. Repetto G, Orlando F, Arduino G: Conchiglie del Mediterraneo. Alba: Amici del Museo "Federico Eucebio"; 2005.

28. Gofas S: Notes on some Ibero-Moroccan and Mediterranean Tricolia (Gastropoda, Tricoliidae), with descriptions of new species. J Mollus Stud 1993, 59:351-361.

29. Scaperrotta M, Bartolini S, Bogi C: Stadi di Accrescimento dei Molluschi Marini del Mediterraneo/Stages of Growth of Marine Molluscs of the Mediterranean, Volume 3. Ancona: L'Informatore Piceno; 2011.

30. Natura Mediterraneo. http://www.naturamediterraneo.com

31. Bouchet P: Les Triphoridae de Méditerranée et du proche Atlantique (Mollusca, Gastropoda). Lav Soc ital Malacol 1985, 21:5-58.

32. Prkić J, Mariottini P: Description of two new Cerithiopsis from the Croatian coast, with comments on the Cerithiopsis tubercularis complex (Gastropoda: Cerithiopsidae). Aldrovandia 2009, 5:3-27.

33. Modica MV, Mariottini P, Prkić J, Oliverio M: DNA-barcoding of sympatric species of ectoparasitic gastropods of the genus Cerithiopsis (Mollusca: Gastropoda: Cerithiopsidae) from Croatia. J Mar Biol Assoc UK 2013, 93:1059-1065

34. Zenetos A, Gofas S, Morri C, Rosso A, Violanti D, Garcia Raso JE, Cinar ME, Almogilabin A, Ates AS, Azzurro E, Ballesteros E, Bianchi CN, Bilecenoglu M, Gambi MC, Giangrande A, Gravili C, Hyams-Kaphzan O, Karachle PK, Katsanevakis S, Lipej L, Mastrototaro F, Mineur F, Pancucci-Papadopoulou MA, Ramos Espla A, Salas C, San Martin G, Sfriso A, Streftaris N, Verlaque M: Alien species in the Mediterranean Sea by 2012. A contribution to the application of European Union's Marine Strategy Framework Directive (MSFD). Part 2. Introduction trends and pathways. Medit Mar Sci 2012 13:328-352

35. Scheltema RS: Long-distance dispersal by planktonic larvae of shoal-water benthic invertebrates among central Pacific islands. Bull Mar Sci 1986, 39:241-256.

36. Zenetos A, Gofas S, Russo G, Templado J: Atlas of exotic species in the Mediterranean, Volume 3. Monaco: CIESM Publishers; 2003.

37. Por FD: Lessepsian migration, The influx of Red Sea biota into Mediterranean by way of the Suez Canal. Heidelberg: Springer-Verlag; 1978.

38. Por FD: Lessepsian migration. An appraisal and new data. Bull Inst Océanogr Monaco 1990, 7:1-10.

39. Abdulla A, Linden $\mathrm{O}$ : Maritime traffic effects on biodiversity in the Mediterranean Sea: Review of impacts, priority areas and mitigation measures. In Maritime traffic effects on biodiversity and potential mitigation measures: a synthesis. Edited by Abdulla A, Linden O. Malaga, Spain: IUCN Centre for Mediterranean Cooperation; 2008:160-168.

40. Raitsos DE, Beaugrand G, Georgopoulos D, Zenetos A, PancucciPapadopoulou AM, Theocharis A, Papathanassiou E: Global climate change amplifies the entry of tropical species into the Eastern Mediterranean Sea. Limnol Oceanogr 2010, 55:1478-1484.

41. Tzomos T, Kitsos M-S, Koutsoubas D, Koukouras A: Evolution of the entrance rate and of the spatio-temporal distribution of Lessepsian Mollusca in the Mediterranean Sea. J Biol Res-Thessalon 2012, 17:81-96.

42. Robinson AR, Leslie WG, Theocharis A, Lascaratos A: Encyclopedia of Ocean Sciences. In Mediterranean Sea Circulation. Edited by Steele JH, Turekian KK, Thorpe SA. London: Academic Press; 2001:1689-1706.

43. Olson DB, Kourafalou VH, Johns WH, Samuels G, Veneziani M: Aegean surface circulation from a satellite-tracked drifter array. J Phys Oceanogr 2007, 37:1898-1917.

44. Sayin E, Eronat C, Uçkaç Ş, Beşiktepe ŞT: Hydrography of the eastern part of the Aegean Sea during the Eastern Mediterranean Transient (EMT). J Mar Syst 2011, 88:502-515.

45. Poulain PM, Menna M, Mauri E: Surface geostrophic circulation of the Mediterranean Sea derived from drifter and satellite altimeter data. J Phys Oceanogr 2012, 42:973-990.

46. Poppe GT, Goto Y: European seashells, Volume I. Hachenheim: Conch Books; 1991.

47. Giannuzzi-Savelli R, Pusateri F, Palmeri A, Ebreo C: Atlante delle conchiglie marine del Mediterraneo, Volume 3. Roma: Evolver; 1999.

48. Cachia C, Mifsud C, Sammut PM: The Marine Mollusca of the Maltese Islands (part II: Neotaenioglossa). Leiden: Backhuys Publishers; 1996.

49. Cachia C, Mifsud C, Sammut PM: The Marine Mollusca of the Maltese Islands (part III: sub-class Prosobranchia to sub-class Pulmonata, order Basommatophora). Leiden: Backhuys Publishers; 2001

50. Cachia C, Mifsud C, Sammut PM: The Marine Mollusca of the Maltese Islands (part IV: the classes Caudofoveata, Solenogastres, Bivalvia, Scaphopoda \& Cephalopoda). Leiden: Backhuys Publishers; 2004

51. Doneddu M, Trainito E: Conchiglie del Mediterraneo: Guida ai molluschi conchigliati. Castello: Trezzano sul Naviglio; 2005.

52. Cossignani T, Ardovini R: Malacologia Mediterranea. Atlante delle conchiglie del Mediterraneo. Ancona: L' Informatore Piceno; 2011.

53. Demir M: Shells of Mollusca collected from the Seas of Turkey. Turk J Zool 2003, 27:101-140

54. Cecalupo A, Buzzurro G, Mariani M: Contributo alla conoscenza della malacofauna del Golfo di Gabès (Tunisia). Milano: Quaderni della Civica Stazione Idrobiologica i Milano; 2008.

55. Aslan-Cihangir $\mathrm{H}$, Ovalis $\mathrm{P}$ : Seasonal variations and structure of the Molluscan assemblage in the Canakkale Strait (Turkey). Acta Zool Bulg 2013, 65:233-250.

56. Zenetos A, Vassilopoulou V, Salomidi M, Poursanidis D: Additions to the marine alien fauna of Greek waters (2007 update). Mar Biodiv Records 2007, 1:e91.

57. Zenetos A, Ovalis P, Houart R: Eastward spread of Ergalatax junionae Houart, 2008 (Gastropoda, Mollusca), a recent alien species in the Mediterranean. J Biol Res-Thessalon 2008, 10:221-223.

58. Zenetos A, Ovalis P, Kalogirou S: Closing the gap: Cerithium scabridum Philippi, 1848 found in the South Aegean (Greece, Mediterranean Sea). J Biol Res-Thessalon 2009, 11:107-110.

59. Zenetos A, Pancucci-Papadopoulou MA, Zogaris S, Papastergiadou E, Vardakas L, Aligizaki K, Economou AN: Aquatic alien species in Greece (2009): tracking 
sources, patterns and effects on the ecosystem. J Biol Res-Thessalon 2009, 12:135-172.

60. Marine Biodiversity and Ecosystem Functioning EU Network of Excellence (MarBEF). [www.marbef.org]

61. Taxonomic on-line Database on European Marine Mollusca (CLEMAM). http://www.somali.asso.fr/clemam/biotaxis.php.

62. Ellenic Network on Aquatic Invasive Species (ELNAIS). https://services.ath. hemr.gr.

63. Marine Mediterranean Invasive Alien Species Database (MAMIAS). http://www.mamias.org.

doi:10.1186/2241-5793-21-20

Cite this article as: Manousis and Galinou-Mitsoudi: New gastropod records for the Eastern Mediterranean Sea and one new alien (Emarginula decorata Deshayes, 1863) for the Mediterranean Sea from NW Aegean Sea, Greece. Journal of Biological Research-Thessaloniki $201421: 20$.

\section{Submit your next manuscript to BioMed Central and take full advantage of:}

- Convenient online submission

- Thorough peer review

- No space constraints or color figure charges

- Immediate publication on acceptance

- Inclusion in PubMed, CAS, Scopus and Google Scholar

- Research which is freely available for redistribution 